San Jose State University

SJSU ScholarWorks

Master's Theses

Master's Theses and Graduate Research

1997

\title{
Comparison of a teacher's and her students' judgements of students' writing
}

Diana Alice Hawley

San Jose State University

Follow this and additional works at: https://scholarworks.sjsu.edu/etd_theses

\section{Recommended Citation}

Hawley, Diana Alice, "Comparison of a teacher's and her students' judgements of students' writing" (1997). Master's Theses. 1579.

DOI: https://doi.org/10.31979/etd.zvs8-szja

https://scholarworks.sjsu.edu/etd_theses/1579

This Thesis is brought to you for free and open access by the Master's Theses and Graduate Research at SJSU ScholarWorks. It has been accepted for inclusion in Master's Theses by an authorized administrator of SJSU ScholarWorks. For more information, please contact scholarworks@sjsu.edu. 


\section{INFORMATION TO USERS}

This manuscript has been reproduced from the microfilm master. UMI films the text directly from the original or copy submitted. Thus, some thesis and dissertation copies are in typewriter face, while others may be from any type of computer printer.

The quality of this reproduction is dependent upon the quality of the copy submitted. Broken or indistinct print, colored or poor quality illustrations and photographs, print bleedthrough, substandard margins, and improper alignment can adversely affect reproduction.

In the unlikely event that the author did not send UMI a complete manuscript and there are missing pages, these will be noted. Also, if unauthorized copyright material had to be removed, a note will indicate the deletion.

Oversize materials (e.g., maps, drawings, charts) are reproduced by sectioning the original, beginning at the upper left-hand comer and continuing from left to right in equal sections with small overlaps. Each original is also photographed in one exposure and is included in reduced form at the back of the book.

Photographs included in the original manuscript have been reproduced xerographically in this copy. Higher quality 6" $\times 9$ " black and white photographic prints are available for any photographs or illustrations appearing in this copy for an additional charge. Contact UMI directly to order.

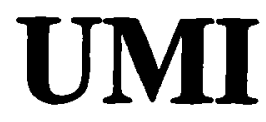

A Bell \& Howell Information Company

300 North Zeeb Road, Ann Arbor MI 48106-1346 USA

$313 / 761-4700 \quad 800 / 521-0600$ 


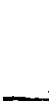




\title{
COMPARISON OF A TEACHER'S AND HER STUDENTS' JUDGEMENTS OF STUDENTS' WRITING
}

\author{
A Thesis \\ Presented to \\ The Faculty of the Department of Elementary Education \\ San Jose State University \\ In Partial Fulfillment \\ of the Requirements for the Degree \\ Master of Arts \\ by \\ Diana Alice Hawley \\ December 1997
}


UMI Number: 1388197

UMI Microform 1388197

Copyright 1998, by UMI Company. All rights reserved.

This microform edition is protected against unauthorized copying under Title 17, United States Code.

\author{
UMI \\ 300 North Zeeb Road \\ Ann Arbor, MI 48103
}


01997

Diana Alice Hawley

ALL RIGHTS RESERVED 
APPROVED FOR THE DEPARTMENT OF ELEMENTARY EDUCATION

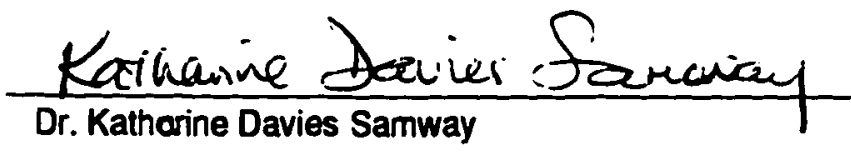

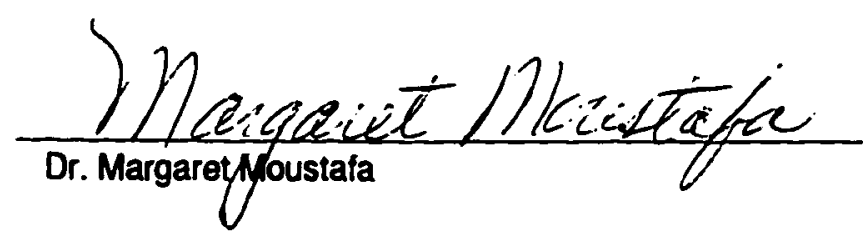

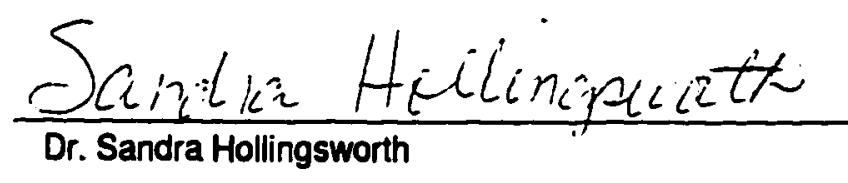
APPROVED FOR THE UNIVERSITY

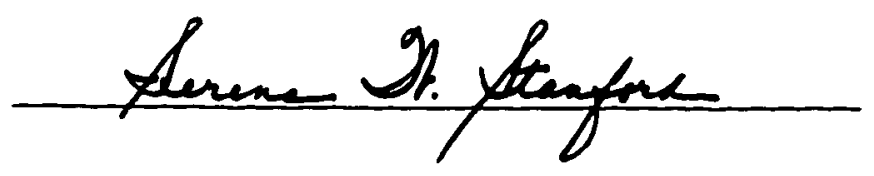




\section{ABSTRACT \\ COMPARISON OF A TEACHER'S AND HER STUDENTS' JUDGEMENTS OF STUDENTS' WRITING \\ by \\ Diana Alice Hawley}

This thesis addresses assessment of students' writing by the students themselves and their teacher. It compares evaluative comments made by the students and their teacher. This study examines similarities and differences in the beliefs of the 10 students and their teacher about writing. The study is based on the results of interviews, surveys and questionnaires.

Research on the subject of assessment reveals that teachers are discovering the importance of process evaluation based on observations and students' self-evaluation. Educators are now looking beyond standardized testing to more authentic measures. Writing teachers are concerned about the way writing is taught. Many teachers are advocating a writer's workshop approach to teaching writing. This approach allows teachers to talk to the students about their writing. As teachers become more informed and interested in their students' thinking and writing processes, this may translate into better performance by students. 


\section{ACKNOWLEDGMENTS}

My heartfelt thanks to my advisor, Dr. Katharine Davies Samway. It has been quite a process working on this study and you have been there all along the way. You have been a great mentor in your college courses and as my thesis advisor and editor. I also consider you a friend and very good listener.

Thank you to the members of my committee, Dr. Margaret Moustafa and Dr. Sandra Hollingsworth. Thanks for your encouragement and patience.

A special award to my husband, Kent Hawley, who knows his word-processor well. Thanks for all your time, patience, expertise and good humor.

Thanks to Nancy Deacon and Melinda Nettles for reading the drafts and offering suggestions along the way. Also, thanks to Juanene Yates for encouragement and help in typing. 
TITLE PAGE

Table of Contents

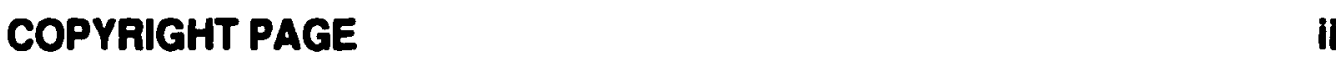

SIGNATURE PAGE iii

ABSTRACT iv

ACKNOWLEDGEMENTS v v

TABLE OF CONTENTS vi

Chapter 1 - Introduction 1

APPROACHES TO WRITING INSTRUCTION 2

ATraditional Approach 2

A Writer's Workshop Approach 3

ASSESSMENT 5

STUDENT SELF-REFLECTION 7

A TEACHER'S ATTITUDES AND BELIEFS 8

Chapter 2 - Literature Reviow $\quad 10$

ASSESSMENT 10

Background 11

Nead For Change $\quad 12$

Portfollo Ascessmont 13

Summany $\quad 17$

THE WRITING PROCESS

WRITER'S WORKSHOP

The Theory Behind Writer's Workshop 19

The Structure of a Writer's Workshop 19

What Does a Writer's Workshop Look Like? 20

Summary 23

STUDENTS' REFLECTIONS AS WRITERS 23

Bating Writing: Critaria 26

TEACHER'S RESPONSE TO STUDENTS' WRITING 27

Backoround $\quad 27$

Eorm vs. Content 28

Alternative Responses to Students' Writing 30

A Word about Mechanics 31 
Summary 32

Chapter 3 - The Study 34

Selecting the Site $\quad 34$

Selecting the Writers 37

COLLECTION OF DATA

Essay Grade Chockllist $\quad 38$

Observation $\quad 40$

Pieces of Writing $\quad 40$

Interviems 41

Writing Surveys $\quad 42$

DATA ANALYSIS $\quad 42$

Twe Comparison Questions $\quad 43$

The Nine Evaluative Categories $\quad 45$

LIMITATIONS OF THE STUDY

Chapter 4 - The Classroom Environment 53

THE SETTING

Writer's Workshop in this Class 53

THE TEACHER

THE WAITERS

BOBERI 55

CINDY 57

BREII 58

ASHTON $\quad 59$

CONMOR $\quad 60$

AMANDA 61

CEDRIC $\quad 62$

CHARLOTIE 63

KEN 65

NINA 66

Chapter 5 - Findings and Discussion 69

FinDinGS 69

Erequency of Siudents' Evaluative Comments 69

Compariston of Sidudents' Evaluative Comments $\quad 69$

Comparison of Each Individual Student's Evaluative Comments with those of the Teacher $\quad 71$

Comparison of all Students' Evaluative Comments with those of the Teacher $\quad 74$

DISCUSSION $\quad 76$

Individual Students Compared to the Teacher $\quad 80$ 
All Students Compared to the Teacher

Chapler 6 - Conclusions and Implications for the Future

IMPLICATIONS FOR TEACHERS

89

IMPLICATIONS FOR FUTURE RESEARCH

81

References

94

Appendix

100 


\section{List of Tables}

Table 1 Essay Grade Checklist 101

Table 2 Writing Sample Interview Prompts 102

Table 3 Writing Survey 103

Table 4 Evaluative Comments: A Comparison of Students 104

Table 5 Evaluative Comments: A Comparison of each Student and the Teacher 105

Table 6 Evaluative Comments: A Comparison of All Students and the Teacher $\quad 106$

Table 7 Evaluative Comments: Ashton and theTeacher 107

Table 8 Evaluative Comments: Cedric and the Teacher 108

Table 9 Evaluative Comments: Char and the Teacher 109

Table 10 Evaluative Comments: Connor and the Teacher 110

Table 11 Evaluative Comments: Kon and the Teacher 111

Table 12 Evaluative Comments: Robert and the Teacher 112

Table 13 Evaluative Comments: Amanda and the Teacher 113

Table 14 Evaluative Comments: Nina and the Teacher 114

Table 15 Evaluative Comments: Cindy and the Teacher 115

Table 16 Evaluative Comments: Brett and the Teacher 116 


\section{Chapter 1 - Introduction}

Writing is a personal, purposeful process that engages the writer in constructing meaning. As a writer constructs meaning, he or she is involved in a creative process, which Doll (1993) calls "self-organizing." He states that self-organizing allows for reflection and idea sharing. Rich information can be gleaned from a classroom that encourages students to share ideas while engaging in the writing process.

Good writing teachers want to help their students discover more about themselves through writing. Searle and Dillon (1980) say that the writing process is basically one of self-discovery in which the writer first discovers, by verbal thoughts and feelings, what meaning he or she has constructed for himself or herself. Self-discovery can take place when writing teachers create an environment where the process approach to writing is used. A process approach to writing helps students organize their thoughts through topic selection, writing, conferring, revising, editing, and publishing or sharing. This process seems linear, but is rather meant to allow writers flexibility to move back and forth through the stages as they write (i.e. new ideas are created and goals are changed in the process of writing). Samway (1992, p. 4) describes writers as "constantly re-reading and re-evaluating their writing, drawing, and organization, and making changes accordingly." 
No two people create meaning in the same way. A writer should be given the power to express his or her own purpose in writing. If a writer is given the power to choose a topic and organize his or her own thoughts before writing, meaning-making can take place. Organization can occur in many different ways.

\section{APPROACHES TO WRITING INSTRUCTION}

There are two different approaches to writing instruction: traditional and writer's workshop.

\section{A Traditional Approach.}

Some classroom teachers choose a traditional approach to teaching writing. For example, in one 6th grade classroom the teacher needs to get her students ready for the annual writing competency test. She knows that the students will have to write about a topic choosen for him or her, so the teacher chooses the topics for the students to prepare them for the test. The teacher gives the topic to the students and expects them to immediately begin to write. They are to work alone and quietly. They are not encouraged to share with peers while writing. The teacher may share a way to plan that she feels works best. The students write a rough draft of their piece and turn it in to their teacher. The teacher checks the piece of writing for good mechanics, spelling and organization. She circles misspelled words and the students later look them up 
in the dictionary and correct them. Then the teacher asks the students to rewrite the pieces and turn them in for a grade. The teacher might use anything from a objective grading procedure to a holistic scale in grading the writing. The grade is put on the piece of writing and then returned to the student. The main purpose for students in this type of writing is to get them ready for the annual writing competency state test. The students' audience is the teacher and the raters.

\section{AWriter's Workshop Approach}

Some teachers have embraced a workshop approach to teaching writing. A workshop environment provides an authentic and natural environment for students to write (Barrs, et al., 1988; Calkins, 1991; Graves, 1983, 1984;

Samway, 1992). Students who work in a writer's workshop environment are encouraged to conference with other students, reflect throughout their writing, and choose their own topics. A writer's workshop approach emphasizes writing in an interrelational, collaborative environment. Students can write together, talk about their writing, and receive advice and suggestions from their peers, not only the teacher.

Calkins (1991) uses a process approach to writing as an instructional focus in her Writer's Workshop. A writing process approach to writing allows students to reflect and self-evaluate throughout their writing. Students select a topic, write, confer, edit and share or publish their piece. They are encouraged to 
talk about what they are doing with others as they are doing it. They move through the process in their own way, at their own pace, and in a recursive (or nonlinear) manner. The steps are set-up as a guideline not as a set path. Students are encouraged to interrelate and self-organize as they write. Writer's usually go through the following stages:

1. Prewriting. Students can create an outline of the main ideas in their topic. It is helpful for students to answer the questions: Who, What, When and Where, about the topic. Students can be encouraged to map out their ideas in the form of a mind map. A picture is often a good way to get ideas flowing. Students individually or collaboratively choose a topic and then draw a picture using words about the topic. Writers need to organize their thoughts in a way that works for them. Throughout the writing process a student is encouraged to conference with other students about ideas and thoughts about their writing. Teacher or peer conferencing can take place throughout the writing process.

2. Drafting. After a student has selected his or her topic, he or she is ready to write. Writers may find it helpful to share topics with a peer or a group of other writers. This helps the writer move toward a better product or stimulate ideas for better writing. It seems to help writers to brainstorm their ideas with others. 3. Editing. Editing is a skill that needs to be taught to students. Students need practice in order to edit their own writing, effectively. In many classrooms, 
teachers encourage peer editing, which is an effective way for students to learn how to search for mechanical errors and give constructive feedback about content. Teacher-editing is often a part of the process, but students should learn to do much of their own editing first.

4. Publishing. Another part of the writing process is finishing and/or polishing a piece of writing. There are many ways of publishing and sharing a piece of writing. In some classrooms, there is an author's chair that students sit in to share their piece of writing with the class. Sometimes the writing is displayed in the room or made into a class book. The writing may be submitted to a children's magazine or the local paper. Ideas for publishing are only as limited as the creativity of the students.

As I go through the experience of writing a research paper, I move through the writing process over and over. I re-read, re-work, and re-evaluate my words. I am learning to understand the recursive nature of writing, as my ideas change and I struggle with the re-working process.

In the remainder of this chapter, I will explore the following themes: assessment, student attitudes and beliefs, and teacher attitudes and beliefs.

\section{ASSESSMENT}

The nature of assessment has been a puzzle for many years. In 1969, 
Standardized tests were widely used as measures of student learning (Sheppard, 1989). Today, tests are not adequate as measures of true student achievement. Tests are being redesigned to more closely resemble real learning tasks. Writing assessment has moved from a focus on the writing product to the writing process (Lindaman \& Lewis, 1989). For years, teachers and students have given a grade on final copies of writing, without considering the process the students went through to get to the final copy. This has led to a shift from indirect measures of evaluating writing (e.g., use of objective test items) to direct measures (e.g., those that call for student writing samples) (Lindaman \& Lewis, 1989).

Researchers such as Donald Graves and Lucy Calkins have tried using meaning-based, authentic ways of assessing students' work. Calkins (1991) suggests that assessment is a "minds-on approach" to teaching. She says that assessment allows us to be student-centered in our teaching. Student-centered assessment focuses on students' growth and includes the collection of students' work to show growth over time. She suggests that it is appropriate to ask two questions when assessing students: 1 . What kind of records are you keeping of your student's growth? and 2. How are you saving students' work? Calkins emphasizes the need for teachers to work out their own method of assessment, according to their assessment needs. 
Student-centered assessment might include the use of surveys to ask students about reading, writing or math. Calkins (1991) asked students to create a coat-of-arms collage that described themselves. This artifact helped to build a portrait of the student. It was a part of the record of the student, a place from which to plan and to set goals (Calkins, 1991). Interviews, anecdotal records and work samples can be collected and used to measure student growth. Student growth cannot be measured by looking at only one piece of their work. Their best efforts need to be measured over time. This understanding has changed the landscape of assessment in the past few years (Calkins, 1991; Farr, 1990; Perrone, 1991; Sheppard, 1989).

\section{STUDENT SELF-REFLECTION}

In this study I assessed students' writing by collecting artifacts and by looking at the self-reflections they made about their writing. Self-reflection is a little-researched subject that is getting more and more attention. The research of McCarthy, Meir, and Rinderer (1985) indicates that students' perceptions of their writing skills are related to their actual writing performance; they also claim that assessment of one's written work can influence it's quality. As self-reflection is encouraged, a writer can discover her or his own strengths and weaknesses (Bunc-Crim, 1992). Self-reflection can be encouraged by the use of open-ended 
questions like, "What was the hardest part of writing today?" or "What is one thing you did better today than yesterday?" As self-reflection is encouraged in students, the teacher allows him or her to control aspects of his or her own learning (Bunc-Crim ,1992; McCarthy et al., 1985; Shor, 1992). There are many unanswered questions about students and self-reflection. Some important questions are: To what extent can students self-reflect during their writing? Are student self-reflections realistic, and are they positive or negative? and What kind of attitudes and beliefs do students have about their writing?

\section{A TEACHER'S ATTITUDES AND BELIEFS}

What are the teacher's attitudes and beliefs about writing and about their students' writing? In the classroom, teachers are often given the task of evaluating student writing. Many advocate putting letter grades on writing. Some of these teachers put a grade on the quality of the form or mechanics of a piece. Others grade the content in a piece. Some teachers grade both. When teachers look at their students' work, do they focus on form, content or both? Do teachers focus on the mechanics of students' writing, or are they more interested in the quality of the content of a piece of writing? Are these perceptions realistic, positive or negative?

Searle and Dillon (1980) found that teachers tend to focus on structural 
concerns and mechanical errors when they grade students' writing. Sometimes a general comment such as "good work" or "interesting" would be written to encourage the student. In Searle and Dillon's research, these responses accounted for over $86 \%$ of the responses made by the teachers who participated in their study. Correctness was the focus of teacher evaluation. This emphasis said to students, "It doesn't matter what you say. What matters is how you say it."

In this study, I will be looking at the teacher's responses to see if she focuses on correctness or the content of the students' writing. 


\section{Chapter 2 - Literature Review}

The review of literature for this study focuses on assessment of writing and teacher and student perceptions of writing, both of which are pertinent to this investigation. The literature may be divided into five major areas: assessment, the writing process, the structure of a writing workshop, childrens' reflections as writers, and teachers' responses to students' writing.

\section{ASSESSMENT}

John E. Bertrand (1991) made this distinction between "assessment" and "evaluation":

Assessment is the gathering of data, based on testing, that provides the information for evaluation to take place. Evaluation usually refers to the process where a teacher collects, analyzes and interprets data to determine the needs of a student. In the classroom, it is nearly always the scores that pupils generate in testing that are used to evaluate students. (17).

The terms "evaluation" and "assessment" are used interchangeably in classrooms. Also, assessment (testing) is not the only method to measure students' knowledge. A teacher can analyze students' work to see their growth and needs. 


\section{Background}

Testing is an old concept. In the Old Testament, Jephthah (Judges 12:5) ordered that all those who approached the Jordan River unable to pronounce the word "shibboleth" should be killed. By doing so, he distinguished between his own men and those of the enemy, who could not say the sound "sh." Michaels and Karnes (1950) argue that those who pronounced the password "sibboleth" failed a very effective, early criterion-referenced achievement test and received immediate feedback. Throughout time, people have been tested, in every culture. In the United States during Colonial times, students were given performance tests on spelling, grammar, handwriting and composition to assess their learning in these areas (Hodges, 1977).

Testing has always been a part of learning for students in the United States. Even at beginning levels of schooling, for example, pre-school and kindergarten, the belief that learning can and should be tested hasn't been challenged (Bertrand, 1991). Since the beginnings of public education, this country has searched for ways to objectify the testing process. The first standardized tests were created out of the statistical work begun by Thorndike and his students in the field of arithmetic in 1908 and in handwriting in 1910. The first popular standardized test was The Thorndike Handwriting Scale (Michaels \& Karnes, 1950; Perrone, 1991). 
By the 1930's, the majority of schools in the United States and Canada were engaged in some form of standardized testing. There was an upward spiral of testing programs after 1950 as they became the basis for selection and retention of students in education programs. Before 1965, tests weren't often given to early grades, but by 1970 , tests set the standards in almost all curriculum areas and at all grade levels (Perrone, 1991). Today, it is almost impossible to take part in schooling at any level without submitting to standardized tests.

\section{Need For Change}

Sheppard (1989) suggests that standardized tests were "reasonable indicators of student learning, 20 years ago, but now are not adequate to evaluate a student's abilities." Calkins (1994) says of standardized tests: "These tests are designed by people outside to control those inside classes." This is especially clear in the area of writing assessment.

The largest breakthrough in the standardized or traditional testing movement is in the area of writing assessment (Perrone, 1991). Students' best efforts cannot be measured by looking at a single piece of their work or work not completed within a classroom (Calkins, 1994; Chapman, 1990; Lindaman \& Lewis, 1989; Perrone, 1991; Ryan et al., 1995; Sheppard, 1989). The best person to judge students' writing and monitor their progress is their 
teacher.

Lindaman and Lewis (1989) saw the need to educate teachers to move away from indirect measures of testing (objective, standardized testing), to direct measures (use of student writing samples). They introduced 150 teachers at the North Scott Community School District in Eldridge, lowa, to a new way of teaching writing. They taught teachers to approach writing as a process, rather than a product only. An assessment project called ANSWER (Assessing North Scott Writer's Essay Reflections) set up direct measures to evaluate the writing curriculum and students' writing. The measures included:

1). Writing Samples - two topics chosen; students worked through the writing process (pre-writing, writing, editing, publishing).

2). Cumulative Folder- compiled from grade to grade.

3). Formal Assessment-trained readers looked at two pieces to determine characteristics of good writing for each grade level.

4). Teacher Survey - teachers completed surveys about their attitudes about writing. (Lindaman \& Lewis, 1989, p. 39 ).

\section{Pontfolio Assessment}

The need for organized classroom documentation gave root to a need for performance- based assessments. One of these assessments has come to be 
known as the portfolio (Calkins, 1994; Cockrun \& Costillo, 1991; Farr, 1990;

Krest, 1990; Olson, 1991; Perrone,1991; Rief, 1990; Tierney et al., 1991;

Valencia, 1990). Portfolios are records of the writer's growth. Farr (1990) says the purpose of portfolios is to collect a variety of materials that can be displayed.

The idea of the portfolio has gained momentum as curriculum experts have called for assessment that includes a variety of work samples and encourages teachers and students to confer with each other about literacy development (Farr, 1990). Portfolio assessment gives the teacher and students valuable information beyond a test. Various professions use the portiolio to gather exemplary samples of performance. Stockbrokers, art students, sales people and those in advertising collect and display materials gathered or produced. Each professional collects work finished or in process to display for various purposes. To be of use, careful consideration needs to be given to what goes into the portfolios, including the process of selection and how the information is to be used (Calkins, 1994; Krest, 1990; Valencia, 1990). Calkins (1994) suggests that a writing portfolio is a "record of the writer's journey, reflecting the turning points, the low moments, the ruts, the breakthroughs, and the mountain peaks" (p. 324). A portfolio can include work in progress and finished pieces, as well as other artifacts (e.g., student surveys and interviews). Sometimes the writing samples are student chosen and sometimes teacher 
chosen. The information can be used for student self-evaluation, teacher evaluation, or displayed to parents or published.

Grades can also be given in the portfolio process without destroying the spirit of portfolio assessment. Students can be involved in their own grading through the use of checklists and interviews (Manning, 1995). Ryan (1993) suggests that a checklist of criteria for a good essay can provide "continuity and consistency" in evaluating student papers. Interviews can provide students the opportunity to evaluate themselves. Teachers can also see the students' attitudes about their writing. This information can be helpful for the teacher and the student. In his study, of 6th-12th grade writers, Ryan (1993) found that having a clearly defined set of guidelines helped both teachers and students become more involved in the process of writing and more effective evaluators of student's writing.

Jay Simmons (in Rief, 1990) and his research team in Durham, New Hampshire, successfully pilot-tested an alternative to holistically-scored, timed writing samples. Their results showed that portfolios with self-selected pieces are significantly better than timed writing samples in determining students writing ability, especially the students with weaker writing skills. In his research, portfolios were used to measure reflection, perception and production across a population of 27 randomly selected 5th graders. Each chose three of their best 
pieces that were completed during the school year. They also wrote a timed test on a given topic. Students and raters looked at student portfolios, recording paper length (number of words on the page), mode of discourse, and range of modes. They also listed strengths of the papers. Student responses were reviewed to see how well their reflections on the qualities of their papers matched the adult raters. When the timed test scores and the median score in the portfolio assessment were compared, the raters found that the timed test significantly underestimated the writing ability of many of the students. The students who scored 2 or 3 on the timed test averaged 4.7 on the median portfolio piece. The students who scored 4 or 5 on the timed test also averaged 4.7 on their median portfolio piece.

At F.S. Key Elementary School, in Arlington, Virginia, Evelyn Fernandez and Susan Baker (1993) used portfolio assessment in a two-way partial immersion program. They collected materials and forms for evaluating and recording student progress. The student component of the portfolio included self-portraits, language attitude questionnaires, writing samples from each grading period, and self-selected best work with self-evaluations. The teacher component of the portfolio included anecdotal records, teacher-selected work, reading miscue analysis (twice a year), end of unit evaluations, optional teacher's log or work samples using word processing software. Portfolios can include 
work the teacher and students value.

\section{Summary}

Forms of testing have existed for many years. In the 20th century, teachers have relied quite heavily on standardized tests to obtain objective assessments. Gradually, teachers are moving toward the use of qualitative evaluation of students. Teachers are seeing the importance of process evaluation based on their own judgements, observations, and students' reflections and self-evaluation. They are finding that standardized tests are inappropriate for the goals they have for students.

\section{THE WRITING PROCESS}

In traditional classrooms, writing has typically been taught using teacher assigned topics and genres with the teacher as the center of attention, stressing correctness. Frequently, the teacher focused on weekly spelling tests, skill-oriented writing instruction and evaluation based on spelling and grammar. Writing was taught as a mechanical sequence (Hamilton, 1992). Like the changes in assessment, there have also been changes in the writing classroom.

In contrast to the traditional classroom, teachers in a writing process classroom do not see writing as a mechanical sequence, but as a social process children engage in to do their writing (Edelsky \& Smith, 1984). Students are 
encouraged to share ideas, draft, revise and confer with each other and their teachers. Students are encouraged to edit their writing. Sharing and publication of work is also encouraged (Calkins, 1983; Graves, 1983, 1985; Heald-Taylor, 1989; Reutzel \& Hollingsworth, 1988).

In a writing process classroom, students have opportunities for daily writing and are allowed to select their own topics and genres. The strategy for process writing in the classroom includes: prewriting, drafting, revising, conferring, and editing (Hamilton, 1992; Calkins, 1983). Doll (1993) describes this process as one which allows creating, reflecting, and sharing. Students move within the process of writing in a non-linear way. For example, a writer writes a draft, edits, rewrites, confers with a peer, revises and then publishes his or her piece. The reflection and sharing helps students self-organize and maintain momentum in writing.

Searle and Dillon (1980) say that the writing process classroom is "a place where writers discover, by verbalizing thoughts and feelings, what meaning they have constructed for themselves" (p. 779). In a writing process classroom, students are given opportunities to reflect and confer as they write, which helps them monitor their own writing. Flower and Hayes (1980) suggest that a large part of the skill in writing can be measured by the writer's ability to monitor his or her own composing process. A writing process classroom can be a healthy 
environment for writers to grow and learn to reflect and share ideas.

\section{WRITER'S WORKSHOP}

\section{The Theory Behind Writer's Workshop}

The philosophy behind writer's workshop views writing as a meaning-making process, not a mechanical process for expressing ideas already conceived (Flower \& Hayes, 1980; Samway, 1992). In school, writing tasks are frequently devoid of the idea that our thinking develops through writing. When students discuss their writing with each other and adults, the children's thinking and writing is enriched (Samway, 1992).

Writing is not a linear process, but is recursive (Doll, 1993; Samway, 1992). Writers move within the writing process to say what they want to say. Students need a simple structure to follow, but not a linear, step-by-step process (Calkins, 1994; Samway, 1992). Recursion and self-organization can take place in an environment where the pattern is interactive and interrelational (Doll, 1993).

\section{The Structure of a Writer's Workshop}

Writer's workshop is a method that provides a natural environment for teaching children to write and make meaning in their lives. More and more teachers are moving away from the traditional classroom approach to teaching, where isolated skills are taught in a fractured curriculum (Calkins, 1994). 
Instead, teachers are leading writer's workshops, which provide a natural environment for students to grow and develop a positive attitude toward writing (Calkins, 1984; Graves, 1994; Strech, 1994). A teacher created writer's workshop environment allows students to write at a predictable time during the school day, with a focus on the writing process, not just the product. Strech (1994) reports that when writer's workshop was conducted with a group of third graders on a daily basis students' attitudes toward writing improved. The percentage of students reporting that they like to write increased from $48 \%$ to $78 \%$. The percentage of students who preferred to choose their own topic increased from $52 \%$ to $63 \%$.

Setting aside a predictable time for writing is important. Teachers who lead writing workshops usually have a writing period three to five times a week for concentrated writing. The writing process requires a radically different pace than we are used to in schools (Calkins, 1994). Students need more time and concentrated blocks of time, preferably one hour, three to five times a week. What Does a Writer's Workshop Look Like?

A writer's workshop can have different structures. The following is an example of a writer's workshop, based on structures described by Calkins (1994) and Samway (1992). This structure begins with a mini lesson. There is work time, peer conferencing and share sessions built into the program. Also, 
students can choose to publish their work and have a publication celebration.

MiniLesson - Mini-lessons are short, whole-class sessions which focus on a particular feature of writing that the teacher or students feel is important. Teachers often choose to begin each writer's workshop session with a mini-lesson on a topic needed by the students. Some examples of early mini-lesson ideas are: writing conferences, revision strategies, editing and publishing. During a mini-lesson, the teacher may say, "Last night, I was looking at your writing and I realized that many of you are having a hard time with something that is also difficult for me... " For example, the task of rereading one's work.

During the first session of a writing workshop, the teacher may help the class generate and select topics by listing high-interest topics on the board and discussing them with the students. Students can list their own topic ideas on a piece of paper to put in a writing folder or portfolio to refer to throughout writing.

Work Time - Work time is for students to write and confer on their writing. Students go to their writing desks or to tables, where they work on their ongoing pieces. Students are likely to be writing on different topics or writing in a particular genre talked about in a mini-lesson (e.g., writing poetry). At the beginning of the year, the class may be working together getting more instruction from the teacher. As the year progresses, students will progress at different 
rates. During writer's workshop, all students write. When one piece is finished, another piece is started.

Conferences - Conferences are usually 5-10 minute-long talks about student progress. Students can be introduced to the conferencing process by the teacher demonstrating the process with a student and asking the rest of the class to listen and watch. Before the student reads his or her piece, the teacher may ask the student what he or she is trying to accomplish as a writer and what he or she likes best about the piece. After the student has read the piece, the teacher may comment on what was liked best and what was learned from the piece. The teacher may ask any other clarifying questions and end by asking the student what he or she will do next with the piece. The class may then discuss what they saw the teacher do and repeat some of the questions the teacher asked. Students may conference with the teacher and/or peers. The teacher or student may initiate the conference.

Share Sessions - The purpose of a share session is to share and support the writer and work in progress. Usually these sessions are in front of a group or the whole class. One example of a share session is allowing students to sit in a special chair to share their piece (Calkins, 1994; McGinley et al., 1992). The students share and receive responses from the other students about their writing. Students are encouraged to refer to themselves and each other as 
"authors". Another possibility is a sharing corner in the classroom, where small groups of student may share their writing with one another.

Publication Celebration - Publishing books can be as easy as sharing final drafts to making books. Some teachers schedule a few students to publish once a week. Other teachers might invite family members to hear their sons or daughters share their finished pieces. Some teachers help students create a book, complete with illustrations, front cover, and information about the author. In these ways, the whole class celebrates the books or finished pieces.

\section{Summary}

Students can grow in an environment where they can make choices (e.g., topic selection), share with each other (e.g., conferencing and share sessions), and write for real audiences (e.g., publishing a book). Within the writing workshop environment, students can learn to bring careful self-examination and solid interpretation to their efforts as writers (Perrone, 1991).

\section{STUDENTS' REFLECTIONS AS WRITERS}

Students' perceptions of their writing skills are related to their actual writing performance (McCarthy et al.,1985). When students discover their strengths and weaknesses, they can control aspects of their own learning. They are empowered by the knowledge of what they are able to do and what they 
want to do better as writers (Bunc-Crim, 1992). The teacher can help this process by guiding students to reflect on their writing. The teacher can plan for self-evaluation throughout the day. One way to do this is by guiding with open-ended questions, for example, "What was the hardest part of writing today?" or "What is one thing you did better today than yesterday?" (Bunc-Crim, 1992; McCarthy, et al., 1985).

Students know a lot about their writing. They know that writing is communication, and they can voice this realization. For example, Yvonne Siu-Runyan (1991), a teacher of 4th-6th grade students, asked the question, "What would you like to learn next in order to become a better writer?" At first she received very little response from students. They offered vague responses,such as, "Write better." After a month of asking the same question over and over again, students began to share more. Examples of some of the things they wanted to learn follow:

I want to learn how to put conversation in my stories (Ashleigh, 4th grade).

I want to learn how to find topics to write about (Silas, 4 th grade).

I want to learn how to develop my characters (D.J., 6th grade).

I want to learn how to spell the word "probably" (Thomas, 5th grade).

(Runyan, 1991, p. 114)

From the students' comments, Runyan learned a lot about the students' writing. 
The students learned that writing is not simply forming letters of the alphabet or spelling words correctly. Most importantly, they learned to verbalize what they wanted to learn (Runyan, 1991). As teachers, we need to listen first to the perceptions our students have of themselves and then address what they can and cannot do (Rief, 1990).

What do students see as important in their writing? Students are interested in their purposes for writing. They have a need to write to a real audience (Calkins, 1994; Long, 1992; Samway, 1992). Not only do students write for the teachers, but they need to write for other reasons. For example, in her conversation with students, Runyan (1991) found that students understood that writing is using written language to communicate. They are concerned about giving a message to readers: peers, teachers, parents and the world, in general.

In Ballard's study (1992), the teacher was surprised at the students' insights into their own strengths and weaknesses. The students tended to be more critical of themselves than the teacher was of them. They recognized the importance of focus, logic coherence and smooth delivery of ideas. Students were also able to notice technical problems (e.g., sentence structure errors, organizing materials, developing ideas). Ballard found that students seemed to have a lot of insight into their own writing, when given the power to evaluate 
themselves.

Bating Writing: Criteria

In research by both Hilgers $(1984,1986)$ and Samway $(1993)$, children demonstrated a considerable ability to evaluate their own writing. In Hilger's and Samway's studies, students were interviewed and asked to give evaluative statements about their writing. These evaluative statements were then categorized and scored.

Hilgers found that evaluative statements from his four participants (1986) could be categorized into five categories, for the most part. One of his categories was based on liking responses. Hilgers noticed that liking responses played dominant roles in the evaluations. These are responses based on liking an element of, or associated with, a text. For example, one student's evaluations focused on liking video games and liking poems. Across the three-year study, students gradually began using other criteria, such as looking at the craftsmanship of a piece to form judgements about whether a piece was good or bad. Even in Grade 4, however, the students continued to make judgements based on liking criteria. Other criteria used by Hilgers were surface-features. The surface-features criteria (e.g., spelling, capitalization, punctuation) were used about half the time as the liking criteria by the children in evaluating writing. (Hilgers suggests that young writers might not use surface-feature criteria as 
readily because they are still learning the conventions associated with the appearance of pieces of writing). In Hilger's study the students focused on content related issues twice as often as issues of form in their writing.

Samway (1993) used a similar set of criteria to categorize students' evaluative comments. Samway gathered data from two pull-out ESOL (English to Speakers of Other Languages) classes. The two classes consisted of a group of eight 2 nd/3rd graders and a group of seven 4 th/6th graders. Samway stated that her most striking finding was "the emphasis that the children placed on crafting issues, regardless of the task or their age" (p. 17). The crafting category focuses on how well a story is developed or what a student neglectes to do. Samway noticed that many of the students were aware of their role as a craftsperson, one who revises to meet a purpose with an audience.

\section{TEACHER'S RESPONSE TO STUDENTS' WRITING}

\section{Background}

Before the 1980's, there was very little said about teacher's perceptions of students' writing. Searle and Dillon (1980b) found that in the 60's and 70's, descriptions of teacher response took place primarily at the secondary and post-secondary levels. Searle and Dillon wanted to look at teacher response at the elementary level, so in their research they collected 135 pieces of students' 
writing collected from 9 teachers. Their findings showed that teacher responses were generally centered on organizational factors, mechanics, and word usage. They suggested that teachers tend to focus on mechanics and correct form, rather than content and function of writing.

Searle and Dillon (1980a) found that teacher responses to content of Students' writing were far fewer in number than the elements of form.

Responses to content were general, less concerned with correctness, and more positive than were the responses to elements of form. The message given to students seemed to be "it doesn't matter what you say, what matters is how you say it" (p.775). They found that teachers spent a lot of time evaluating according to mechanics, and other elements of form.

Gary Grobe (1981) analyzed student expository writing in 1979. He found that holistic quality scores awarded by teacher raters were influenced to a great extent by essay length and freedom from spelling errors. Mechanics and length of the story were more important to teachers as they evaluated students' writing. These teachers tended to focus on form (mechanics) in their evaluations of student writing.

Form vs, Content

The results of the previous studies represent traditional notions of how teachers approach writing. Searle and Dillon (1980a) suggest that there are two 
important theories of the language learning process. First, language use is purposeful and meaningful. Our attention centers on the purposes we are trying to convey in language, not on language itself. Second, there is no separation of the learning of language (form) and the learning of purposeful, meaningful use of language (content). Language is learned by the use of it (Searle \& Dillon, 1980a).

The results of the Searle and Dillon study show that many teachers operate with a different theory, particularly when responding to students' writing. They tend to focus primarily on form rather than content. Searle and Dillon suggest that teachers also seemed to "separate the learning of language from the purposeful use of it" (p. 775). They illustrate this point through the following hypothetical conversation illustrating how a conversation might sound if speakers focused on the form of the language rather that the content:

Teacher: (answering door) Hi!

Friend: I'm sorry l'm late, but a funny thing happened to me on the way to your house this evening.

Teacher: That's an awfully trite way to begin your conversation. Try to be more original.

Friend: I was driving along when I hear this high-pitched, whining, abrasive screech from the engine. 
Teacher: Those are good descriptive words!

Friend: Just then I come to a service station.

Teacher: You "came" to a service station.

Friend: Worried to death about my car, the service station attendant told me it wasn't serious.

Teacher: You misplaced your modifier.

(Searle \& Dillon, 1980a, p. 775).

This conversation underscores the notion that for some teachers, it doesn't matter what a person says, but how it is said. Researchers are concerned that teacher responses tend to focus on form. This may discourage students from focusing on the message, instead focusing on "correct" language (Atwell, 1987; Collins, 1991; Searle \& Dillon, 1980a,b; Ziv, 1980).

\section{Alternative Responses to Students' Writing}

Students may write better and more meaningfully if encouraged to communicate more with their audience. Nina Ziv (1980) suggests that teachers should make comments in a positive and empathetic manner, always trying to understand the intention of student writers. She also suggests that teachers need to move away from the role of evaluator toward establishing dialogue with student writers (Ziv, 1980). The most useful sources of information teachers can use for assessment are the conversations they have with students about their 
writing (Runyan, 1991). It is important to respond with questions and reactions that are directly aimed at the "quality of expression" in the writing (Searle \& Dillon, 1980a, p. 777).

Searle and Dillon (1980a) suggest that teachers might be more effective if they tried responding more to content rather than form. For example, in the role of teacher as audience, teachers could respond by asking questions which would clarify any confusion about the content of the piece. For example, the teacher could ask a student some content-related questions (e.g., What will happen to the character next? or What were you trying to say or do here?). The teacher could also ask for elaboration or make suggestions to the student (Searle \& Dillon, 1980a). These questions focus on meaning and content, which help students focus on what is rnost important in writing.

\section{A Word about Mechanics}

Content or meaning is central to writing. Mechanics or the form of writing are a part of this meaning-making process, as Searle and Dillon (1980a) point out:

Learning the mechanics of writing is a developmental process - like learning to walk, talk, or draw - which occurs as a continuing refinement of the whole process of composing and which should occur as part of an environment focused on meaning. (p. 779). 
Searle and Dillon suggest that since learning mechanics is a developmental process, elementary teachers should not force students to master mechanics prematurely. A student can learn to self-edit, according to his or her individual developmental level. It is not beneficial for a teacher to correct all the mechanical "errors" in a piece of writing (Collins, 1991; Searle \& Dillon, 1980a, 1980b; Ziv, 1980). Searle and Dillon (1980a) suggest that it is better to choose one or two aspects of mechanics which are important and focus on those. Scannel and Marshall's study (1966) suggest that it is better to selectively correct mechanical errors. This leads to a greater mastery of mechanics over the long-term.

As students are ready to learn more mechanics, teachers can meet with them in teacher-student conferences. In a writer's workshop, mechanical issues can be addressed in mini-lessons, when most of the students have a common need.

Summary

Not all writing requires a response, but when responses are given, teachers need to keep the meaning-making process in mind. Teacher responses can make a difference in students learning to write. Positive, empathetic responses from teachers can help students become more confident writers. Also, if teachers respond to content, not just form, they can help children 
discover their own way of expressing themselves. 


\section{Chapter 3 - The Study}

\section{Selecting the Site}

In order to observe and question writers as they evaluate their writing, I looked for an environment that encouraged self-reflection. A classroom with a functioning writer's workshop provides a rich climate for students to plan their own work and assess what they have done (Calkins, 1994; Graves, 1984). I was looking for a classroom that stimulates children to write freely when they wanted and about what they wanted. I felt that in this environment I would be more likely to encounter children who were comfortable reflecting on their writing. Advocates of a writer's workshop approach to teaching writing say that it encourages self-reflection (Atwell, 1990; Calkins, 1994; Doll, 1993; Graves, 1984; Searle \& Dillon, 1980; Thompkins, 1992).

I needed to locate a classroom teacher who incorporated writer's workshop and was open to participating in research. I wanted the study to be valuable to the teacher as well. She needed to help me select some of the assessment tools for the study. Calkins (1994) stresses the importance of teachers developing their own system of assessment. For my study to be meaningful to the teacher and the students, I needed to involve the teacher in the selection of assessment tools. I wanted to select the grade level carefully. I preferred an upper elementary level because of the interviewing processes 
involved in the research methodology. I was interested in the self-evaluations of upper elementary children.

Sally Sloan, a fellow student in the Master's of Education program at a local university, invited me to her 5th grade classroom to observe her writing program. She teaches in a 5 th grade class at a private school in an urban community. The school, St. Philipe School, is in a multicultural urban neighborhood. There were twenty students in the classroom. Sally was using a writer's workshop approach to teaching writing, encouraging children to choose their own topics, pre-write/plan, write, edit and publish. She conducted writer's workshop one hour, two times a week. I visited Sally's classroom during writer's workshop, two times a week for six months, January to June. Each workshop session lasted one hour.

Two days a week I volunteered in her class during the writing period. She asked me to listen to students talk about their writing and give advice, as needed. Sally and I often spoke about our writing philosophies. Sally was using a writer's workshop approach to teach writing. She was seeing great progress, with students conferencing with peers about their writing. She could see that they were learning to evaluate their own work. We both agreed that a writing process approach to teaching writing is an effective way to teach writing.

In one of our discussions, Sally and I discussed our feelings about 
grading. Sally often commented to me that she wasn't pleased with her method of grading students' writing. She also didn't think students agreed with her about the quality of their writing. For example, she might grade Susie's writing with a "B," but Susie didn't appear to understand why she got a "B." There wasn't a grading standard used by both the teacher and the students. We discussed this concern and set out to find a solution.

Conversations with Sally led me to embark on the study described in this thesis. We wanted to explore three questions: 1 . What are the students' judgements about their own writing? 2. What are the teacher's judgements about the students' writing? 3. To what extent do the students' and teacher's judgements differ? These questions eventually became the primary questions of this study.

Sally wanted to explore assessment tools that could be used to evaluate her students. She and I looked at several assessment tools that might help us explore students' perceptions about writing. We researched tools that had been used previously to prompt students to be self-evaluators. We settled on the following assessment tools/data collection instruments: Essay Grade Checklist, Observation, Interviews, Writing Samples, and Writing Surveys. (These tools will be discussed in more detail in the "Collection of Data" section.) 


\section{Selecting the Writers}

The teacher and I selected 10 students for the study who represented a cross-section of students' writing performance. We chose students who were at all levels of ability in Language Arts so we could get a more valid sampling of results. The two criteria used in choosing students were class standing in Language Arts ability and male/female status. The teacher and I collaborated in identifying participants for the study.

Sally determined class standing by looking at the Language Arts grades across the whole class. In the beginning of the study, we chose six students, two with high grades, two with average grades and two with low grades. Three of these students were boys and three were girls. All of the students were native English speakers.

In the beginning of the fourth month, April, we decided to add four new students as we felt that we needed more pieces of writing to study. We used the same criteria for selection of students. We chose one more student with high Language Arts grades, one with average grades and two with low grades. In the final two months, a total of 10 students were participating in the study - five boys and five girls. There were three high students, three average students and four low students, based on using class standings. 


\section{COLLECTION OF DATA}

The purpose of this study was to compare the perceptions of students and a teacher about the students' writing. The research design utilized aspects of qualitative research, including participant observation, collection of written samples, writing surveys and interviews.

As a participant observer, I helped the teacher during writer's workshop, while also obsenving students as they wrote. As a facilitator, I walked around the room, answering questions, and met with students for conferences upon request. As an observer, I took field notes while students wrote. Most of my time was spent interviewing students, using prompts from the assessment tools we chose for this study.

The following is a description of each of the assessment tools used in this study: Essay Grade Checklist, Observation, Interviews, Writing Samples and Writing Surveys. The reasoning behind the choice of the tool is also given.

\section{Essay Grade Checklist}

When I interviewed Sally's students in January, they told me they didn't know why they were receiving their writing grades. They asked, "What does a 'C' mean on this writing piece?" They didn't understand why they were getting a particular grade on a piece of writing. In a conference with Sally, we decided we needed some kind of grading criteria to use with the student pieces. We were 
searching for a way to demysuify scoring and grading of writing, as grading seemed to lack consistency. Creating a clearly-defined set of guidelines for a writing program can create continuity and consistency in evaluating (Ryan, 1993). DeFina (1992) compiled a descriptive marking scale consisting of 10 criteria, which he called an Essay Grade Checklist(see Table 1). We liked the questions, so decided to use the criteria. The checklist is included in DeFina's model of a student portfolio. We chose this checklist because it contained criteria that Sally believed to be important indicators of a good essay and it could provide consistency in her evaluation of students' writing. Sally emphasized the 10 criteria when teaching writing. In writer's workshop, she emphasized organization, voice, grammar, and descriptive language. She also discussed with the students the importance of good punctuation, capitalization and editing procedures. She felt comfortable using this checklist to evaluate students' writing. We felt the checklist might help both the students and Sally be more objective in the evaluation/grading procedure.

Sally introduced the checklist to the 10 students selected for the study and explained each criteria in detail. The students were told that they were involved in a research project, so would be asked to fill out the checklist for three of their pieces of writing. She also told them she would fill out the checklist for the same three pieces of their writing. Sally also explained the range score of $0-10$ to the 
students. They were asked to rate themselves according to the 0-10 range, with 10 high and 0 low.

Students were also given a copy of the essay grade checklist to use during their editing time. For example, they could check their piece to make sure that there was an appropriate beginning, middle and ending section, which coorresponds with the second element on the essay grade checklist.

\section{Qbservation}

I collected field notes during the two hours of writer's workshop each week. I observed students as they conferenced with each other. I tape-recorded students talking about their writing. I observed students as they conferenced with each other. I paid attention to how they interacted with each other on a joint writing piece, or how they used each other as peer editors.

The teacher gave background notes to me about each student. She included the student's class standing in Language Arts. She included information about the students' interests and social skills. This background knowledge about students helped me to develop a better profile of each writer.

\section{Pieces of Writing}

I collected three pieces of writing for each student, with a total of 30 pieces of writing from all 10 students. The students' stories included genres ranging from descriptive paragraphs to poetry. Students submitted their pieces 
of writing, when completed. In this way, we collected three pieces of writing from each of the 10 students. Each piece of writing was duplicated.

Interviews

Each writer was interviewed three times about each of three of their pieces written during Writer's Workshop. Students chose two out of three of their topics. One out of the three pieces was assigned. This piece was to be a descriptive paragraph describing the directions from school to home. These pieces will be entitled "How to get to my house from school" or a similar title.

When students completed a piece of writing, they evaluated it by completing an essay grade checklist (see Table 1). Sally and I set up a box for the students to turn in their writing with the checklist attached. As I received the writing with a checklist attached. I intenviewed the writer, reading the piece and reviewing the checklist. I then interviewed each student using the writing sample prompts from The primary language record: Handbook for teachers (Barrs, et al., 1988) ( see Table 2). This tool included prompts that I hoped would reveal teacher and student judgements of the writing.

The teacher received each student's piece of writing without a checklist attached. The teacher read the student's piece, filled out the same essay grade checklist form and returned it to me. I interviewed the teacher after she read each student's piece. 


\section{Writing Surveys}

Students completed a writing survey. I used the writing survey questions from Nancy Atwell's In the middle; Writing, reading and learning with adolescents (Atwell, 1987) (see Table 3). I interviewed students using a writing survey to gather more information about students' perceptions of themselves as writers.

Calkins (1994) states that surveys are a valuable tool to help assess students. As a researcher, I need to ask myself how these surveys reveal what I need to know about a student. Surveys can reveal insights into a writer's attitudes about writing.

\section{DATA ANALYSIS}

Data collected from the Essay grade checklist (Table 1) was helpiul for the teacher as she evaluated the writing of the students. She averaged the score she gave on a checklist with the student's own score to arrive at a grade for each student's piece of writing. I drew on the data from the observations and responses to the writing survey to write the profiles of each student in the next chapter.

The primary sources of data were interviews with the teacher and students and the writing samples. The writing samples were used to help create 
the student profiles, using exerpts from student writing Data were collected from all of the interview prompts (Table 2). Responses to two of the prompts could be easily coded and organized into nine categories. I chose to categorize the evaluative responses to these two prompts because I felt they provided the data that addressed my research question. The prompts, from the Writing Sample Interview Prompts (Table 2), were as follows: 1. The child's or teacher's response to the writing, and 2. What this writing shows about the child's development as a writer. Student responses and teacher responses could then be compared using the nine categories. I asked the students two questions, formulated from the two prompts:

\section{Iwe Comparison Questions}

The first question was formulated from the interview prompt, The child's or teacher's response to the writing. I asked the students, What is your response to the writing? Rate the pieces as favorite (1), O.K. (2), and least favorite (3). Students were asked to put a "1" on the piece, if it was a favorite. A "2" means O.K. and a "3" means least favorite. Students could put a "1" on all three pieces, if they all were favorites. The teacher also was asked to number each students three pieces with a "1", "2", or "3." The teacher and students also had to indicate why they chose the piece as a "1", "2", or a "3." I recorded students' and the teacher's responses. I then grouped the responses into eight 
categories: evaluative, crafting, organization, liking, mechanics, entertainment, risk-taking and miscellaneous.

The second question comes from the interview prompt, What this writing shows about the child's development as a writer. I wanted to know what kinds of growth the student's and teacher noticed about the writing, so I asked the question, Are there any important changes since the last writing? Both the teacher and students noticed specific changes most of the time. In a few instances, they said that there was no particular growth noticed. All the responses were recorded, so the category no growth needed to be included as one of the categories. The responses were coded using nine categories: evaluative, crafting, organization, liking, mechanics, entertainment, risk-taking, miscellaneous, and no growth. A description of the nine categories will be discussed in the next section.

Student and teacher responses to the two questions were coded using similar categories. I read through the data and scored each evaluative comment according to a modified version of Hilgers' $(1984,1986)$ and Samway's (1993) categories for evaluative statements. When all the comments were put into categories, the students' and teacher's comments could be compared by category for similarities and differences. The categorizes are described in detail in the following section. 


\section{The Nine Evaluative Categories}

Responses to the above questions: What is your response to the writing? Rate the pieces according to your favorite piece, an O.K. piece, and least favorite piece., and Are there any important changes since the last writing? were scored as members of one of nine categories: value-related, crafting, mechanics, liking, entertainment, organization, miscellaneous, risk-taking and no growth. These nine categories were used to compare student and teacher responses.

When either a student or the teacher offered the same response in more than one utterance the comments were scored as a single instance. In cases where there was more than one utterance and they corresponded with different categories, each comment was scored as an instance of each of the categories. The following is a list of the categories, including examples of student and teacher comments for each:

1. Organization - These were comments related to logic and organization of a piece. They deal with comments on how a piece was organized and whether the piece was complete or not. Some examples of comments on organization were:

It is logical

It was well-organized 
These comments also related to completion or lack of completion of the writing:

I left street names out...not complete.

He doesn't always finish his work, but did finish his poetry.

Comments in this category also related to the length of a story:

I was more confident because it was short.

I wrote a long piece.

2. Mechanics - Comments in this category related to the form of the text (e.g., spelling, punctuation, capitalization, and sentence structure):

She made mistakes...words were left out.

She had only one spelling error.

I had lots of weaknesses.ttoo many commas and not enough periods.

She used quotes correctly.

Comments like 'there were no mistakes' were also categorized as mechanics.

When comments were made about poetry, students and the teacher often commented about rhyming of the text:

It rhymes

The rhyming form wasn't right

Comments relating to the mechanics of a piece are not concerned with the content of the text.

3. Crafting - Responses had to do with how well a story had been 
developed. These comments showed the author as craftsperson, one who strives to accomplish a purpose with an audience. Examples of these comments were:

\author{
Her piece kept the reader's interest \\ I had strong content \\ She expressed herself well
}

Many questions dealt with the amount of description and detail used by the author:

Lots of specific detail

She expanded her ideas more and used more descriptive writing

Many comments were made about the ability to do something well:

Used actual chapters in the story

Used good jargon

Used flashbacks

Spent a lot of time on this piece

Other responses were comments on what the students neglected to do:

She needed more background information

He could have been more informative

Could use better description

Some children referred to elements that had been discussed regularly in their 
mini-lessons during their writing time:

I should have used more descriptive language

I made interesting organization choices

I used more descriptive writing

These issues deal more with content than form of writing.

4. Liking - These are subjective comments that reflect personal liking or not liking a piece. Examples of this type of comment are:

I really liked this piece

I liked this kind of music

I felt strongly about this idea

Many students commented that they didn't like writing about a topic that was required:

I prefer to choose my own topic idea

I didn't like writing this because it was required

5. Value-related - Comments that focused on "the value of what a piece of writing intends to do, what it does, and how well it does it" (Hilgers, 1984, p. 378) may be found in this category. Comments in this category also had to do with whether or not the writing was easy or hard and if it was one of the better things written. Hilgers and Samway found very few comments in this category. In this study the students made more value-related comments than the teacher. 
Examples of student comments in this category are:

It was hard trying to figure out where the roads were

This was not as good as my science piece

This was a tough piece

It was easy to write, but not easy to find the ideas

I was more confident because it was short and easy

The teacher made value-related comments on occasion:

This was not as good as his science piece

The subject matter and cartoon were immature

6. Risk-taking - Comments that mentioned "first time" something was

done, were part of this category. If students picked a new type of writing they sometimes made comments such as:

I picked a new and interesting subject to write about

I used new material and a new subject

I learned a different type of poetry

Comments that showed students taking a risk in their writing included:

This was the first time to write a long piece. I wrote a chapter story

This was the first time to write a story with a buddy

It was the first time to try doing a comic strip

Some students tried a new genre: 
I tried a new genre in public writing - autobiographies. I've only written about this in my private diary.

She used a new genre - fiction

Tried a new genre - poetry

7. Entertainment - These comments show the degree to which a comment generated an emotional response. Examples of this type of response are as follows:

I did a good job making it funny

I had fun writing it

It was boring to write. It didn't excite me

This piece made writing more fun

Hilgers (1986) included entertainment as a sub-group of the miscellaneous category. Samway (1993) used entertainment as a separate category because she wanted to clearly establish the degree to which students referred to the category. Entertainment will be used as a separate category in this study, also.

8. Miscellaneous - In most cases the comments could be classified as belonging to one of the other eight evaluative categories. Some of the comments made by students and the teacher didn't fit clearly into a category. Samway called her miscellaneous comments "idiosyncratic" (Samway, 1993). I found this to be true of a few comments made by Ms. Sloan and the 10 students 
in this study. Some examples of these comments were:

Wish I could have asked Mom about it

This assignment was not assigned

9. No Growth - This is one of the possible responses to the question: Are there any important changes since your last writing? The response "none" was given by students or the teacher when they felt there was "no growth" shown in a particular piece. For comparison purposes, this category is one of the nine categories of possible comments.

\section{LIMITATIONS OF THE STUDY}

In the coding of responses, single or two word answers (e.g., good, pretty good) were often ambiguous, making it hard to code them. It is possible that in an effort to place them in a category, I placed them in the wrong category. In retrospect, I think it would have been better to have probed the students for less ambiguous responses. For example, one student said, "I liked it." I could have asked," What did you like about it?", but I didn't. I coded it under liking. In fact, the student could have been commenting on, for example, a crafting issue (e.g., "I liked using poetry."). Probes can give more information to help us understand the students' thinking processes in their writing.

One of the possible responses to the interview question, Are there any 
important changes since your last writing?, was that there were no important changes. This response was put into the category no growth. This response doesn't seem to fit in with the other eight categories as an evaluative category. Since this response was given in some instances by students and the teacher, it had to be included in the results.

"Pseudonyms have been used for all named individuals in this study, as well as the school name and city name. 


\section{Chapter 4 - The Classroom Environment}

\section{THE SETTING}

\section{Writer's Workshop in this Class}

The teacher, Sally Sloan, conducted a writer's workshop two days a week for one hour each day, from 10:30-11:30. I gathered data at this time.

At the beginning of the hour, Sally asked her students to get their writing folders. Children at each table, consisting of 4 desks, took turns picking up their folders from a box in the writing center area of the classroom. In the writing center, there was paper of different kinds, an 'in box' for finished pieces, and an 'out box' for edited pieces or pieces the teacher had read and responded to. There was also a file of student folders or writing portfolios, filled with each student's "writing in process" and finished pieces. Students brought these folders to their desks.

The teacher asked each student to give an update on the progress of his or her writing. One student might be beginning a piece, another might be in the editing stage of writing, and one student might be ready for a conference with the teacher about his or her finished piece. Sally wrote down an update of student progress. After the update, Sally gave a short 5-10 minute mini-lesson (Atwell, 1990; Calkins, 1986) to the class. She selected the lesson according to student needs (e.g., When the students were having a particularly difficult time with 
description in their writing, she gave a mini-lesson about descriptive writing). When the mini-lesson was over, students began working on their writing.

As a participant observer, I interviewed students as they finished their pieces. I asked them to comment on their finished pieces (see Collection of Data, Chapter 3). When I was nnt interviewing students, I was observing the students as they wrote. A student could ask me questions about her or his piece of writing. I would listen and comment or ask a question to get more information (e.g., What is your favorite part of this piece?)

\section{THE TEACHER}

Sally Sloan, the teacher, was a student in the Master's of Education program at the nearby university, where she was studying reading and writing instruction. She was very interested in her role as teacher/researcher. She was open to change and wss looking for an effective way to evaluate her students' writing. She expressed continual interest in the research findings and how they would help her be a better educator.

Ms. Sloan encouraged good writing in a caring, yet assertive manner. Each day, she started her writer's workshop period with mini-lessons. In these mini-lessons, she focused on issues of story development, organization and mechanics. Ms Sloan believed that good writers focused on the elements of 
organization, story development, detail, and mechanical correctness.

\section{THE WRITERS}

Since St. Philipe school was a small private school, most of students came from a middle or high-middle class background. All 10 target students were in the middle to high-middle socio-economic class. All 10 students spoke English as their first language. Students were all in grade five and their ages ranged from 10 to 11 . The student population at the school was generally highly motivated.

In order to provide well-rounded information about each participant, I will include a brief personal history on each. In the following section, I will introduce the writers, their interests, and attitudes towards writing.

\section{BOBERI}

Robert is an average student, according to his academic class standing in Language Arts. He is 10 years old. Robert is quiet and is sometimes sensitive about being shorter than most of his classmates. He has dark hair and is Caucasian. He enjoys sports, especially soccer.

About reading and writing, Robert said: "People learn to write by learning to read. A good writer needs to be able to communicate and have good ideas." He wants to be a better writer and "Get more ideas, more quickly." Robert 
seems to have a good sense of what makes a good writer and how to be a better writer himself.

Robert wasn't afraid to take risks with new genres (e.g., prose, poetry). In one of his pieces, he did some extensive research to find out about the different human body systems. He accurately presented scientific facts in his "Science" story. He also tried a new genre for the second piece. He worked with a partner to create a poem called "The World's Messiest Room." He was pleased about this piece because "It was fun to do writing with someone else. The ideas came more quickly." In his third piece, Robert was asked to write an explanatory paragraph. He didn't know how to explain how to get to his house, so he asked his Dad to help. He explained: "Dad helped me map out my house, using a magnifying glass to find the important streets." Robert knows how to find a topic and seeks help for revision using a variety of resources such as a thesaurus, dictionary and encyclopedias.

According to Ms. Sloan, Robert has made a lot of progress with description and detail in his writing. In one interview with Ms. Sloan, she said, "Robert usually writes short works, but he spent a lot of time with research to find facts for his piece 'Science."' In Robert's interview, he commented about this piece, "This was one of the better things l've done. It was longer, with a good subject. It helped me study a lot." At the beginning of the study, Ms.Sloan told 
me that Robert had a difficult time expressing himself in writing. Ms. Sloan and Robert agreed that he was developing a good sense of detail in his writing.

\section{CINDY}

Cindy is a high student, according to her class academic standing in Language Arts. She is 10 years old and has long, dark, brown hair. She has many friends. She is Caucasian. Cindy loves to play soccer.

Cindy really enjoys writing poems. Continually reading poems and trying different poem ideas, she prefers poetry to other genres. In one of her interviews, she said, "Writing poetry is fun. I had an old song stuck in my head, so I wrote about it. It made writing more fun." Ms. Sloan said that Cindy chooses to write poetry a lot. She noticed improvement in Cindy's poem, "Oldies But Goodies." The teacher said: "Cindy had good rhymes, and stayed on the subject." Cindy moved out of the poetry genre in one of her pieces, "St. Patrick's Day," which was a biography. She did the necessary research with help from her teacher. She had a difficult time with this piece; she said she didn't like writing complete sentences and didn't like doing research in the encyclopedia. She prefers to write about her interests.

Cindy knew where to find the information she needed for her writing. She consulted with the teacher and encyclopedia on one piece and discussed another with her parents. 
Sally would like to see Cindy write more poetry, striving to increase the length and substance. She said Cindy likes to create imagery in her writing. Ms. Sloan liked Cindy's piece "Oldies But Goodies." She said it showed growth in creative imagery.

\section{BREII}

Brett is an average student, according to class standing. He does well in Language Arts, but struggles when asked to do any written work. He doesn't seem to have confidence in his ability to write. He is Japanese-American, but is an English-only speaker. He is shy around other children and it is difficult to hear him when he speaks. He has a good grasp of the English language.

Brett is good at taking risks in his writing. He enjoys trying new genres. He wanted to try writing humorous stories and stories about new and different topics. His piece, "Mega Man VII," was a real stretch for him, according to Ms. Sloan. About his story, Brett said, "I have never written a long story before." This particular story was several pages long. He was proud of the writing he had done. Brett knows how to ask for help (e.g., from his mom and the teacher). He found magazines at the store and in the library about Mega Man for his story "Mega Man VII" and for information for his piece, "The Planets and Their Moon." He asked for help from other students with his story, "The Planets and Their Moon," especially as he was doing the first draft of the piece. 
Brett likes his stories. He gave all three of his stories a "1", naming them all as his favorite. He commented favorably in the interview on each of his pieces. For example, when commenting on "How to Get to My House," he said, "This piece fits well as one of my favorites. It is accurate."

Sally said that Brett is writing with much more detail, as compared to his writing at the beginning of the year. She said he was "very creative" in "The Planets and Their Moon." She said he spent a lot of time on all three pieces. Sally said he needs encouragement in his writing. She said his writing really improves when he is given encouragment.

\section{ASHTON}

Ashton is working at the top of her class in Language Arts, especially in reading. She is Caucasian with long blond hair. According to Sally, she is a caring person, friendly, and athletic. She enjoys reading realistic fiction most of the time (e.g., "Song of the Trees," by Mildred Taylor). Ms. Sloan reported that Ashton devours literature and is always anxious to read the next book. Ashton feels that when readers come to something they don't know, they should look at the context. She said good readers look at context in a story to find answers to questions. She said she learned to read in Kindergarten with the teacher's help. She is engaged in the excitement of learning through literature. She often writes about something she has read about in a book. 
Ashton is an observer of life around her, often finding interesting and diverse topics. She spends time in the library and asks the librarian for assistance. As a writer, she knows how to use a variety of resources, from materials to individuals.

Ashton used quotation marks correctly in her stories, especially in her story "The Girl and Science." Sally said, "Ashton is now using quotes correctly in her first piece of fiction." She also uses a lot of descriptive language, for example, in "Liz: The Sea Creature Girl," she described the ocean in detail. In "The Girl and Science," Ashton used descriptive language to make her story more interesting. For example, she described one of her characters as "extremely frustrated" at one point in the story.

\section{CONNOR}

Connor is at the top of his class in language arts. He is Caucasian with light brown hair and an athletic build. He comes from a family with high expectations. His parents are involved in his education and are concerned that Connor get his work done correctly. They encourage him to bring written work home for corrections, whenever possible. He enjoys reading and says that he learned to read at school and from his parents. His favorite authors are Franklin Dixon, Roald Dahl, and Gertrude Chandler. He said, "l'd like to be able to read 7th and 8th grade books with lots of slang " (e.g., Huckleberry Finn). He feels 
that people write in order to express their feelings and to tell their stories. In his interview, Connor said, "I think good writers come up with their own ideas, write stories people would like to read, and include a variety of settings, characters and story problems." He likes the stories he writes. When describing his stories, Connor said, "I think they contain good ideas, some humor and they do a good job describing the things l've done." Sally said about Connor, "He is improving in substance and content of his writing. He is knowledgeable about his subjects." Connor seems to be very concerned about the content of his writing and often chooses to write about sports because he claims it is meaningful to him and to his audience. He loves to have his friends read his stories and often chooses to write a joint story with another friend (e.g., he wrote a joint story with Robert, "The World's Messiest Room"). He wants his readers to understand his interests and get as excited as he is about his topics.

\section{AMANDA}

Amanda is an average student in her class in Language Arts. She is 10 years old, Caucasian, with naturally curly, dark hair. She is outgoing and friendly and loves to play sports. She said she learned to read from her Mom reading to her and from reading a lot. She likes to read adventure and mystery stories. Her favorite authors are Roald Dahl and Zilpha Snyder. Amanda feels it is important to be a good reader because a good reader is also a good writer. One of her 
stories, "Dino Planet," was written after a visit to Lawrence Hall of Science and after reading a fiction book about dinosaurs. She was so enthusiastic about the book and museum trip that she asked Ms. Sloan to teach about dinosaurs. Amanda gets enthusiastic about her topics, doing research and finding out more about her topics.

Amanda is very concerned about her spelling and grammar. She feels that Ms. Sloan values correct mechanics in writing. In all three interviews, Amanda expressed that she wanted to be a better speller and use better grammar and descriptive language. She could have been projecting the teacher's expectation into her own image of what makes a good story. She seemed to strongly desire affirmation from the teacher. She often focused on what she thought the teacher wanted (e.g., good grammar and mechanics). However, it's interesting that, in the interview, the teacher focused on Amanda's content, saying, for example, "Very well done. Well-developed. Lots of suspense. Good use of flashback."

\section{CEDRIC}

Cedric is a working at a low level according to class standing in Language Arts. He prefers Science activities over Language Arts. Writing is sometimes difficult for him. He is Caucasian, with sandy, brown hair. He is friendly to others, and has a lot of friends. He enjoys reading, even though he reads slowly 
and has a difficult time with comprehension. He didn't have a favorite author or book. He likes to get writing ideas from fiction books and says he wants to write only fiction stories. He has a good imagination, so he loves to write about adventure and suspense. He used a lot of imagination in his story, "The Mystery of the Triangle," which was written in journal style about exploring the Bermuda Triangle. He also wrote and illustrated a story with a friend, "Rawlden's Ridge," inspired by a poltergeist story he heard. One of Cedric's strengths is an active imagination. He enjoys writing when he can create interesting stories.

Cedric is concerned that he doesn't use enough detail in his writing. In his interview, Cedric said that Ms. Sloan really likes detail in writing. He would like to be better at creating what he called "well brought out detail." He seemed to be concerned about the teacher accepting and enjoying his pieces. He had a very good sense of purpose in his writing. For example, he didn't think the assignment, "Directions to my House," was useful. He said, "This information was not useful. I would never forget the way to my house, so why write about it." Cedric expressed a desire to be able to choose his own topic in the future. He wanted to write about topics that were meaningful and purposeful to him.

\section{CHABLOTIE}

Charlotte (Char) has difficulty in Language Arts activities. Her difficulties with word attack skills place her in a low level in Language Arts class standing. 
She is Japanese-American and has short, dark hair. She is friendly, yet timid. She asks for help from her teacher when things get difficult. She uses good comprehension strategies by accurately answering questions, as she reads. She expressed a desire to be a better writer, indicating that she wanted to be able to use better grammar and be more consistent indenting her paragraphs.

Char said she likes what she writes, but sometimes has trouble thinking of what to write about. As a writer, she looks for topics in math books and glossaries, and also asks adults. She said she really likes math and prefers to write about math topics. Char prefers choosing her own topics because she likes having a purpose in writing.

As a writer, Char takes risks by choosing a variety of genres that are new to her. For example, she wrote a chapter story entitled "True Story" about her life experiences. Char also wrote an acrostic poem on math facts that was both accurate and interesting. Again, Char chose a genre, poetry, that was new to her.

Char thinks her teacher values spelling and "working hard on the story," and was very careful to spell accurately. In her first piece, "The New Ride," she used a spell check on the computer for words she wasn't sure about. She looked in the dictionary for the difficult words for her other two stories. The teacher's impression of Char's spelling in "The New Ride" was that it was "very poor." Char said, "My spelling is not that great." She expressed a desire to be a 
better speller in all three of her interviews.

\section{KEN}

Ken has a difficult time with Language Arts activities. He was rated by his teacher as a low student according to Language Arts class standing. Ken has good self-esteem and is outgoing and friendly. He is Caucasian with blond hair and blue eyes. He is conscientious and works hard for his grades. He likes to help others in class and on the playground.

He enjoys reading mysteries, adventure stories, sports stories, army books and has tried to read " The Hunt for Red October." He said it was a "very hard book to read." He likes the authors, Matt Christopher and Franklin W. Dixon. He feels that good readers are good writers.

He learned to write in first grade, using little tablets and copying ABC's on a page each day. He said about writing, "People write because they have something in their mind and they want to write it down and get it out of their mind." He feels that good writers are full of good ideas and pictures in their minds. He said, "I like to talk and write about my dreams. One of my wishes is to be able to write many more stories about my dreams. I really like my dreams about surfing." About his piece, "How to Get to My House from School," he said, "It's hard to write how you get home. I would rather just explain it out loud." When he talked with his Mom about this piece, he was much more interested 
and involved. He likes to create and role-play orally and in his writing. According to the teacher, when he's interested and engaged in his writing, he tends to write more than usual.

When asked the question, "How does your teacher decide which pieces of writing are the good ones?" Ken replied, "Teachers decide on a grade, using some of their own criteria, and the ones with the high grades are the good pieces of writing." He didn't know what the criteria were until we started using the Essay Grade Checklist to score the writing. He appreciated having knowledge of the criteria used to score his writing.

\section{NINA}

Nina has difficulty with Language Arts activities. The teacher placed her in the low level according to class standing in Language Arts. Nina is Caucasion with dark, naturally curly hair. She is hesitant to try things that seem difficult. She is self-conscious about her tendency to be ovenweight. She gets into social battles with her friends, which she often tries to resolve with the help of the teacher. Nina enjoys sharing her stories and her social activities with her teacher, which are often reflected in her writing.

Nina likes to read adventure and fiction stories. Her favorite authors are Ann M. Martin and Alvin Scharts. She said she likes reading some of the time. She was hesitant to give answers to the questions about reading and writing. It 
could have been a lack of trust on her part. According to the teacher, she enjoys sharing deeply with adults, but is slow to trust.

She thinks people learn to write by reading different types of books and by practicing reading. She feels people write because it's a hobby for them and they enjoy reading. She thinks that good writers write several drafts, edit and do other "Writer's workshop stuff." She thinks her teacher will tell her what she needs to do to improve her writing. About her writing, Nina said, "I am afraid some of my writing might offend someone. If so, I would gladly rewrite the offending page." Nina has a very keen interest in her audience. She has a clear sense of audience. She likes to tell her audience about the big issues of life: love, friendship, prejudice, hate and fear. Much of her writing deals with things that are happening in her life. For example, she said, "My piece "True Story" is important to give to the audience." In this story, Nina talked about how hard it was to tell another person to "stop bugging her and to leave her alone." She talked about how hard it was to confront without hurting someone. This seems to be a tough issue for most kids. Nina dealt with the tough issues in her writing.

She does seem to need encouragement as she writes. For example, her teacher talks with her about her personal problems and daily encourages her to have more confidence in herself both as a writer and individual. The teacher reminds Nina that she is good at expressing herself with strong content. Nina 
shows pride in her writing sharing with the teacher and other students in authors circle or peer sharing time. 


\section{Chapter 5 - Findings and Discussion FINDINGS}

The data give us insight into aspects of the childrens' and teacher's evaluative criteria. In this chapter I will compare evaluative comments made by all of the 10 students. I will also discuss evaluative categories used by the teacher, and I compare all students' evaluative comments with those of the teacher. In this discussion, I will draw upon the following data: case studies of the 10 students, interviews with the teacher and students, and student writing surveys.

Erequency of Students' Evaluative Comments

The highest percentage of student comments focused on issues of liking (Table 4). Students focused on liking issues $22 \%$ of the time. As a whole, they focused on crafting issues $19 \%$ of the time. One other category, mechanics, accounted for $16 \%$ of all comments generated. There were fewer comments in the risk-taking (13\%), value-related (11\%), and entertainment (8\%) categories. No growth (4\%) miscellaneous (4\%) and organization (3\%) categories accounted for very few student responses.

Compariston of Students' Evaluative Comments

There was considerable variation in the range of criteria used by students (see Table 4). A comparison among students reveals 2 out of 10 students 
(Ashton and Ken) referred to crafting issues most of the time and 2 out of 10 students (Brett and Char) referred to liking issues the most. Robert referred to both crafting and liking issues an equal amount of time. Nina referred to mechanics, liking and entertainment equally. Cedric referred to issues of crafting and risk-taking an equal amount of time. Cindy made comments in the category of entertainment the majority of the time. Connor made value-related comments most of the time. Amanda made comments in the category of mechanics most of the time. At least one student made a majority of his or her comments in all categories with the exception of organization, miscellaneous, no growth, and risk-taking.

All of the students made at least one comment in the categories of liking and mechanics. Neither Connor, Ashton, Amanda, Cedric or Char generated any entertainment comments, whereas most of Cindy's comments ( $40 \%$ ) fell into the entertainment category. Variation also existed in the value-related category. The range was from no responses for Brett, Ashton, Ken and Amanda to $36 \%$ of Connor's responses. All but one student, Nina, responded to issues of crafting. Other students commented as much as $36 \%$ (Ashton) on crafting.

Issues of crafting accounted for at least $27 \%$ of the responses for four students: Robert (31\%), Ashton (36\%), Cedric (27\%), and Ken (33\%). Issues of liking accounted for at least $23 \%$ of responses for four students: Robert (31\%), 
Brett (33\%), Nina (23\%), and Char (36\%). Most of the 10 students commented on issues of liking and crafting.

Comparison of Each Individual Student's Evaluative Comments with those of the Teacher

Each student's comments can also be compared to the teacher's comments by category (Table 5). Responses were considered similar if there was less than a $20 \%$ difference. Responses were considered markedly different if there was a $\mathbf{2 0 \%}$ or more difference between responses in a category. If neither the teacher nor the student commented in a category, the category will be called a zero category, and will be counted as a similarity.

Ashton and the teacher had the most similar types of responses. She and the teacher made a similar number of comments in all nine categories: crafting, mechanics, liking, risk-taking, miscellaneous, no growth, value-related (zero category), entertainment (zero category), and organization (zero category). Ashton and the teacher did not have any categories that had a $20 \%$ difference or more (Table 7).

Cedric had seven categories similar to the teacher: value-related, mechanics, liking, organization, miscellaneous, entertainment (zero category) and no growth. He and the teacher only had two categories that showed a marked difference; risk-taking (T-0\%,S-27\%) and crafting (T-60\%, S-27\%). 
Cedric made many of the same kind of comments as the teacher about his writing (Table 8).

Char also made seven similar responses to the teacher in the value-related, mechanics, organization, miscellaneous, risk-taking, entertainment (zero category), and no growth (zero category) categories. The teacher and Char's differences were in the categories of crafting (T-63\%, S-14\%) and liking (T-0\%, S-36\%) (Table 9).

Connor and the teacher made similar responses in seven areas: mechanics, no growth, liking, miscellaneous, nisk-taking, entertainment (zero category) and organization (zero category). The differences were in value-related (T-0\%, S-36\%), and crafting (T-67\%, S-9\%) comments (Table 10).

Ken and the teacher made similar responses in seven of the categories: value-related, crafting, mechanics, liking, entertainment, organization (zero category) and miscellaneous (zero category). Significant differences were seen in areas of risk-taking (T-0\%, S-22\%) and no growth (T-20\%, S-0\%) (Table 11).

Robert had seven categories similar to the teacher: value-related, risk-taking, crafting, mechanics, entertainment, miscellaneous (zero category) and no growth (zero category). They responded differently with categories of liking (T-0\%, S-31\%) and organization (T-25\%, S-0\%) (Table 12).

Amanda and the teacher made similar responses in six areas: liking, 
organization, miscellaneous, no growth, value-related (zero category) and entertainment (zero category). She and the teacher differed in categories of crafting (T-79\%, S-9\%), mechanics (T-0\%,S-36\%) and risk-taking (T-7\%, S-27\%) (Table 13).

Nina and the teacher had six similarities. They were similar in categories of value-related, mechanics, organization, miscellaneous, risk-taking and no growth (zero category). They differed with issues of crafting (T-50\%, S-0\%), liking (T-0\%, S-23\%) and entertainment (T-0\%, S-23\%) (Table 14).

There were more differences displayed by the remaining two students: Cindy (4 differences, 5 similarities) and Brett (4 differences, 5 similarities).

Cindy had five categories similar to the teacher: mechanics, organization, liking, miscellaneous and risk-taking (zero category). Four areas were different between Cindy and the teacher: value-related (T-0\%, S-20\%), crafting (T-38\%,S-10\%), entertainment (T-0\%, S-40\%) and no growth (T-25\%, S- $0 \%$ ). Cindy was one of only four who made comments in the category of entertainment. The teacher only made three entertainment responses, none of which were for Cindy's writing (Table 15).

Brett and the teacher had five similar categories: risk-taking, no growth, value-related (zero category), entertainment (zero category), and miscellaneous (zero category). Brett and the teacher had four differences: crafting (T-70\%, 
S-22\%), mechanics (T-0\%, S-22\%), liking (T-0\%, S-33\%) and organization (T-0\%, S-20\%) (Table 16).

The range of student responses compared to the teacher is from all 9 similarities in categories (Ashton and teacher) to just 5 similarities (Cindy and teacher; Brett and teacher). One of the 10 students had 9 similarities to the teacher. Five students had 7 similarities, two students had 6 similarities and two students had 5 similarities to the teacher. Eight out of 10 students (Ashton, Cedric, Amanda, Nina, Connor, Ken, Robert, and Char) had similar responses in over $65 \%$ of the categories. Brett and Cindy had similar responses in over $50 \%$ of the categories. All 10 students made over half of their responses in similar categories as the teacher.

Comparison of all Students' Evaluative Comments with those of the Teacher

The teacher's comments can also be compared with all of the students' comments combined (Table 6). The teacher made a total of 112 evaluative comments and the 10 students made a total of 112 evaluative comments.

The largest percentage of comments by the teacher focused on issues of crafting (54\%). The students comments were more widely dispersed among the categories. The highest percentage of their comments was in the category of liking $(22 \%)$. The students made $19 \%$ of their comments in the category of crafting. In contrast, only $1 \%$ of the teacher's comments were in the category of 
liking, the most frequently used category by the students. The teacher made only one response to liking and that was a response to Ken's writing: "He has increased interest in writing."

The teacher responded $15 \%$ of the time to issues of mechanics. The students responded $16 \%$ of the time with comments related to mechanics. Mechanics was the second most frequently used by the teacher and the third most frequently used by the students. The categories of mechanics (T-15\%, $\mathrm{S}-16 \%$ ) and miscellaneous (T-3\%, S-3.5\%) were the most similar between the teacher and the students.

Students made 15 comments in the category of risk-taking (13\%). The teacher only made $3 \%$ of her response in the category of risk-taking (T-3\%, S-13\%). Students also made almost $10 \%$ more responses than the teacher in value-related comments(T-2\%, S-11\%). Students made $8 \%$ of their responses in the category of entertainment. The teacher made $3 \%$ of her responses in this category (T-3\%, S-8\%). The teacher made more responses in the category of organization (12\%), which was a category stressed in the classroom during mini-lessons. Students only commented $3 \%$ of the time in this category $(\mathrm{T}-12 \%$, S-3\%).

According to the criteria determining similarities and differences in the previous section, there were two categories that I considered markedly different: 
crafting (T-54\%, S-19\%) and liking (T-1\%, S-22\%). There were 7 categories that I considered similar: value-related (T-2\%, S-11\%), mechanics (T-15\%, S-16\%), entertainment (T-3\%, S-8\%), organization (T-12\%, S-3\%), miscellaneous (T-3\%, S-3.5\%), risk-taking (T-15\%, S-13\%), and no growth (T-8\%, S-4\%).

In the interview question, What important changes are there in the writing?, the teacher and the students could respond with "none." This response is recorded as no growth. The teacher responded with no growth nine times (8\%). The students responded with no growth five times (4\%). This response means they didn't think there was growth in the writing compared with past writing.

\section{DISCUSSION}

The students were able to critically evaluate their own writing using many different evaluation criteria. Like the children in Samway's 1993 study and Hilger's 1986 study, these children displayed a broad knowledge of writing processes. The students responded to the interview questions and surveys with their own perspectives on good writing. Each student seemed to express what he or she thought was important in writing.

The teacher, Ms. Sloan, also expressed her writing philosophies through 
her conversations with me and through her mini-lessons and conferences with the children. Ms. Sloan and the students had both similar and different responses to the students' writing. The findings in this research suggest some important similarities and differences in the students' and teacher's criteria when evaluation writing.

One of the most striking differences was the variety of types of responses by each of the children. The students' (and teacher's) comments were categorized into 9 categories. The 10 students had a total of 112 comments. The students' comments tended to fit in one or two main categories, but these categories differed according to the child. For example, Brett and Char's comments focused primarily on liking criteria. Most of Ashton and Ken's comments were crafting related. The majority of the other six students' comments focused on different categories and combinations of categories:

Robert- liking and crafting; Nina- mechanics, liking and entertainment; Char-entertainment, Connor-value-related; Amanda-mechanics; Cedric-crafting and risk-taking. There was considerable variation in evaluative criteria. In many cases, these differences were unrelated to the students' ability as writers. The range and focus of these students' evaluative criteria was also highly idiosyncratic, as Samway found in her 1993 study.

The students tended to rely on certain criteria as they commented on 
each of their pieces. For example, Ashton was likely to make crafting comments. She made twice as many crafting comments as she did any other type of comment. She often commented about her need to have better descriptive writing or her ability to use good content in her stories. Another student, Amanda, tended to make comments that were mechanics related. A large percentage of her comments focused on the use of punctuation. She said she didn't like the way she used punctuation in her writing. It seemed important to her to maintain correctness in all her writing.

Some of the differences between Ashton and Amanda can be explained by looking at their interest level in writing. (Data on writing attitudes were collected from the Writing Survey (Table 3), which was used in interviews of each student early in the study.) Ashton really enjoyed writing stories about topics that were new and interesting to her. In response to the survey question, What do you think a good writer needs to do in order to write well? she answered, "They need to know good English and have a good imagination." She also commented that she felt like her ideas were good. She considered herself to be a good writer. Amanda was a developing writer who struggled with the writing process and was very concerned about being a better speller, as seen by her comments (e.g., She commented several times, "I want to spell better.") Amanda didn't consider herself to be a good writer, according to the 
interview question, Are you a writer? In the interview, she indicated that she thought her teacher valued spelling and grammar. Spelling and grammar were areas she didn't feel proficient in. It is possible that she based some of her evaluation of writing on what she thought the teacher expected. This comparison of two students, Amanda and Ashton, is just one example of the differences in the writing attitudes and judgements the students in this study.

The influence of the teacher is seen in cases where there were only infrequent instances of a particular criterion. Samway, in her 1993 study, found few liking and surface features comments, which she said was reflective of the attention the teacher placed on certain aspects of the writing process, for the teacher did not stress mechanical accuracy. Instead she focused on the need to look at the content of a story. Similarly, in this study, students made very few comments in the areas of entertainment and organization. I did not see the teacher spending instruction time focusing on these issues. She focused primarily on issues of crafting. The students made some comments in the category of mechanics, but not as many as some other areas (e.g., liking and crafting). This focus of the teacher seems to be seen in the small percentage of comments about mechanics and larger percentage of crafting comments by students. 
Individual Students Compared to the Teacher

One of the most interesting results was the degree of similarity in typed of comments generated by the teacher and each individual student. There were 9 categories of student and teacher responses about the students' writing. For example, when comparing the teacher's comments and the student's own comments about a piece, Ashton made the most similar comments to the teacher. Ashton and the teacher made comments in 6 of the categories and made no comments in the remaining three categories (entertainment, organization, and value-related). The categories with no responses (called zero categories) were considered similarities, so Ashton and the teacher had similar comments in all 9 categories. Cedric, Char, Connor, Ken, and Robert had comments in 7 categories similar to the teacher.

Two students (Amanda and Nina) made similar comments to the teacher in six areas. Brett and Cindy made similar comments to the teacher in 5 out of 9 categories. Eight out of the 10 children (all except Brett and Cindy) commented $65 \%$ of the time in categories that were similar to the teachers. Brett and Cindy made similar comments to the teacher in over half of their responses. It was remarkable how similar the teacher's responses were to individual students. The teacher seemed to be well aware of her students' strengths and weaknesses in writing. For example, the teacher said that Robert's piece, Science, was taking a 
risk because it was a longer piece, as well as self-corrected. Robert said it was a challenge to write Science because there was a lot to cover on the subject. He also liked his self-correcting in this piece. As these comments illustrate, the teacher and Robert made very similar responses in this case. Similarily, Char did a lot of research for her piece, Mathematics. She said: "I looked at other resources, the glossary, to get ideas outside of myself" About Mathematics, the teacher said: "She worked on this piece over time. She did some research like a previous time." In the interviews, Ms. Sloan was able to give the background of the students' writing and discuss the changes she saw in each student's writing. She showed interest in her students and spent time conferencing with them about their writing. She was aware of her students' thinking processes.

The teacher and the students also had some differing judgements. Brett was one of the students whose comments differed a lot with the teacher. He and the teacher had three zero categories (value-related, entertainment, and miscellaneous), and two other similar categories: risk-taking (T-11\%, S-10\%) and no growth (T-0; S-11\%). However, the teacher and Brett had four differences: crafting (T-70\%, S-22\%), mechanics (T-0, S-22\%), liking (T-0, S-33\%), and organization (T-20\%, S-0). Brett focused on liking comments, for example, "I liked it, might do more," "I like science," and "I like to choose humorous topics." The teacher focused on crafting criteria when commenting on Brett's writing, for 
example, "He is starting to put more detail in his writing," "This is a stretch for him." "There is lots of detail in his work," and "The story Mega Man VIl was logically developed in order of the seven enemies." The teacher put lots of emphasis on attending to crafting issues in her mini-lessons. She often taught students to develop the details of the story and focus on good development. Her comments reflect her beliefs and focus in writing. Brett seemed to have internalized some important aspects of good writing because the teacher noticed a lot of good detail and development in his writing.

Cindy was one out of four students who made comments in the category of entertainment. About $40 \%$ of her total responses were in the entertainment category. The teacher didn't make any comments in this category for Cindy. Cindy's judgements contained emotional words like fun, excited, and boring. About her story Oldies But Goodies, she said, "It was fun to write, because it's about great music." She added, "This topic made writing more fun." About her piece, St. Patrick's Day, she said: " I wasn't too excited to finish it, because it took forever to do." She thought of writing as an interesting (or boring) task, depending upon the topic. She had strong feelings about her writing, which showed in her evaluative comments. In contrast, the teacher made comments on her ability to focus on a topic and her good use of detail. Most of the teacher's comments about Cindy's writing focused on issues of crafting. The 
teacher seemed to think highly of Cindy's ability to write well. Both the teacher and Cindy thought Cindy was an accomplished writer, but for different reasons. They both expressed their beliefs about good writing through their judgements; Cindy through issues of entertainment and the teacher through her crafting related comments.

The teacher only made one liking comment. Her comment was about Ken's piece, Drunky. She commented that she didn't like the subject matter and the cartoon he drew. In an interview she told me she really disliked the piece. She felt it was distasteful. This was the only time Ms. Sloan expressed a like or dislike about the students' writing. In contrast, students frequently made liking comments about their pieces. The category of liking was the least used by the teacher. It seemed much more natural for the teacher to make crafting comments than to make liking comments. Brett and Char made the most comments in the area of liking. Both students like writing, according to their interviews. Char liked her writing in two of her pieces and disliked the assignment in How te get to my House. She made very few crafting comments, whereas the teacher made many when talking about Char's writing (T-63\%, S-14\%). The teacher focused on story development in Char's pieces, The New Ride and Mathematics, In Char's piece, How to get to my House, the teacher talked about good topic sentences and good detail. In a comparison of Brett and Char to the teacher, 
there was a contrast between liking and crafting comments. In the next section, the teacher will be compared to all of the students, as a group.

\section{All Students Compared to the Teacher}

The students made a total of 112 comments across the 9 evaluative categories. The teacher also made 112 comments across the 9 categories. About $22 \%$ of the students responses were in the category of liking. This was the highest percentage of responses from the students as a whole. The highest percentage of teacher's comments were crafting comments (54\%). The students made crafting comments about $19 \%$ of the time. The content of the piece seemed to be very important to all of the evaluators. Issues of form (e.g., mechanics) ranked 3rd for students and 2nd for the teacher. The teacher and students seemed to agree that judgements should be made based on a stories' content, not only on it's surface features.

Both students and the teacher made several comments in the area of crafting. Like the students in Samway's 1993 study, the students were conscious of the importance of crafting when they were writing. Ms. Sloan arranged time during her writer's workshop (in mini-lessons) to discuss criteria for building the overall quality of stories. She stressed writing stories that were focused on providing information so the audience would have a clear understanding of the meaning of the story. It is reasonable to conclude that Ms. Sloan was very 
influential in helping the children evaluate their own writing, especially with regard to crafting issues. For example the students generated comments that had to do with the lessons stressed by the teacher:

Good beginning, middle and end

Good descriptive writing

I had good organization in this writing

The crafting comments made by the students seemed to relate heavily to the classroom environment and the influence of the teacher.

Like Samway's older students (4th-6th graders) in her 1993 study, the students in this study could step back and critically analyze the content of the writing. For example, Cedric, in his story, Bawlden's Ridge, said he used good flashbacks and liked writing with a friend for the first time. He said, "I learn to write better from experiences with other people or from their mind." He also said he really liked what he wrote and illustrated and thought it was creative. He felt he was weak in writing explanatory paragraphs. Cedric's comments were an example of the types of critical self-evaluations by the students about their writing.

The teacher's instruction during the mini-lessons seems to have made an impression on students because they used some of her ideas in their evaluative comments. In addition, the teacher showed interest in the student's writing 
processes in her conferences with them in the writer's workshop setting. This interest seemed to encourage students to share more of their thinking about writing. 


\section{Chapter 6 - Conclusions and Implications for the Future CONCLUSIONS}

The students seemed to have an active desire for conversation about their writing processes. They liked talking about their purposes for writing. In her mini-lessons, the teacher often spoke about the need to write for a real audience. Students focused on meaning and content in their self-evaluations.

The ten students showed remarkable skill in their ability to think about and verbalize their judgements of their own writing. They were able to critically evaluate themselves as writers. They always knew why they chose a certain piece to write about, and they were able to verbalize growth and growth patterns in their writing. The teacher also was able to answer questions about how the students' writing came into being. She had an idea of how the writing arose and had opinions of how each of the students changed as writers.

The teacher, Ms. Sloan, seemed to believe that the development of a story and text-based elements were most important. For the teacher, crafting issues held a much higher precedence over mechanical issues in her judgements of student writing. She seemed to believe in content over form in the teaching of writing. The teacher's evaluative comments matched the elements she taught in her writing instruction mini-lessons. In her mini-lessons she focused on content more than form. Both the teacher and the students focused 
on content-related issues when making their evaluative comments.

The data suggest that there were more similarities than differences between the teacher and the students when evaluating the students' writing. They both focused primarily on issues of content. Over half of Ms. Sloan's comments were on crafting elements and almost half of the students' comments were divided between issues of liking and crafting. One difference between the teacher and students was that the students made many more liking comments than the teacher. The differences became more apparent when individual students were compared to the teacher. For example, most of the teacher's responses to Brett's writing were crafting comments. In contrast, Brett's comments in fell primarely in the crafting, mechanics and liking categories. The teacher made $25 \%$ of her comments about Cindy in the no growth category indicating that she didn't see growth in the writing in two out of three of Cindy's pieces. In contrast, Cindy didn't make any comments in the no growth category. Instead she saw growth in her own writing. Most of her comments focused on issues of entertainment and a combination of crafting, liking, value-related, mechanics and organization. Cindy was one of the few students who made comments in the category of entertainment. The teacher only made three comments in entertainment. 


\section{IMPLICATIONS FOR TEACHERS}

Strech (1994), Calkins (1984) and Graves (1994) state that writer's workshop helps create a more positive attitude toward writing, particularly if there is a predictable time set aside, daily, for a period of concentrated writing. The 10 students had about six months of experience with a consistent writer's workshop period, which seemed to help them be more reflective writers. Teachers who believe in teaching writing as a process should consider using a workshop approach to teaching writing. In a writer's workshop, students have more opportunities to reflect and have conversations with the teacher and each other. In a traditional writing class students often work through the writing process alone without conferences. Consequently, the teacher may not be aware of students' thinking as they work on their writing. Runyan (1991) states that the most useful source of information for teachers is the conversations they have with students about writing.

The students showed a remarkable awareness of the many different aspects of writing. This information is important for teachers. As students rated their writing as favorite, O.K., and not my favorite, they discovered what they knew about writing. The teacher can also find out more about students' attitudes and beliefs about writing. Writing surveys were an important part of the evaluation process, as well. The ratings of student stories coupled with a good 
writing survey can be beneficial to teachers in the assessment of students' writing.

The data in this study suggest that there are some questions a teacher can ask students that might help them be better self-evaluators. In this study, I found that the most effective questions were open-ended. For example, the question, What is your response to the writing? gives some rich data about what students and teachers think is important in writing. They were also asked to rate the piece according to favorite, O.K. or not a favorite. Students and the teacher then explained their ratings. Another question that produced rich data was, Are there any important changes in this writing? Both the students and the teacher gave critical and insightful responses to this question. These questions helped me discover teacher and student judgements about writing. Atwell's writing survey (Table 3) included questions such as, Are you a writer? These data showed student attitudes as writers and gave insight into each writer's confidence in his or her own abilities as a writer.

Eight out of ten students made comments in similar categories to the teacher $65 \%$ of the time. The other two students made similar comments to the teacher about $40 \%$ of the time. Another implication for teachers, then, is the indication that students seem to be influenced by what the teacher values in writing. Ms. Sloan spent a lot of instructional time talking to students about story 
content. The influence of the teacher could be seen in infrequent instances of responses in certain categories (e.g., mechanics). The area of mechanics was not given a lot of attention by the teacher, in either mini-lessons or conferences. Instead, she focused on story development and adding descriptive words to a story. Most students made very few responses related to mechanics. They focused on what they liked about a story and how well a story was been developed.

It is important for teachers and researchers to focus observations on student behaviors that can reveal rich information on writing and the thinking process. Teachers need to know the thinking processes of their students. Observations, questionnaires, surveys, etc. should all be a part of a teacher's assessment plan for each student in writing and other academic areas. These tools can help teachers find out what students think is important. This extra interest might translate into better performance from the students.

\section{IMPLICATIONS FOR FUTURE RESEARCH}

This study raises questions that deserve attention. What are some other tools (e.g., surveys, questionnaires) that might capture attitudes and beliefs about writing? What other tools could teachers use to help students evaluate their own writing? Research suggests that self-evaluation in writing is an 
important process for students. Students create meaning as they reflect on their own work. It would be interesting to discover other tools and activities that might help teachers assess students as they write.

Secondly, is a holistic grading scale more reliable for evaluating writing? Holistic grading scales are quickly becoming popular tools for assessment in reading, writing and math. Teachers have found that these types of scales are reliable tools to assess students' thinking processes. A holistic writing scale can give a wide range of information about the writer, helping the teacher observe more of the learning process. The students also receive more information about their progress as writers. In future studies, a researcher could evaluate students' writing using a holistic grading scale, and compare these results with students' self-evaluation. Students could help create the scale.

Thirdly, what about a different student population? This study could be repeated using a different student population made up of fewer students, allowing for more in-depth case studies. The student population could also be made up of students who are learning English. Samway (1993) did a similar study with students who were learning English as a Second Language. It would be interesting to conduct a study with second language students and their teacher, comparing judgements about the students' writing. This study could also be repeated with students in lower elementary grades, junior high, or in high 
school. In lower grades, puppets could be used as a tool for assessment. The puppets could ask well-designed questions to help assess students' writing attitudes and beliefs. 


\section{References}

Atwell, N. (Ed.) (1990). Coming to know: Writing to learn in the intermediate grades. Portsmouth, NH: Heinemann.

Atwell, N. (1987). In the middle: Writing, reading and learning with adolescents. Portsmouth, NH: Boynton/Cook.

Atwell, N. (Ed.) (1990). Workshop 2: Beyond the basal. Portsmouth,NH: Heinemann.

Ballard, L. (1992, Feb.). Portfolios and self-assessment. English Journal, 81, 46-48.

Barrs, M.; Ellis,S.; Hester, H. \& Thomas, A. (1988). Inner London Education Authority (ILEA), Center for Primary Education. The primary language record: Handbook for teachers. Portsmouth,NH: Heinemann.

Beaman, R. (1990). Alternative student assessment in advertising copywriting, ERIC Document, \#ED323554.

Berthoff, A. (1984, Feb.). Response to Richard Gebhardt, writing processes, revision and rhetorical problems. A note on three recent anticles. College Composition and Communication, 35, 95.

Bunc-Crim, M. (1992, March). Evaluation: New tools for new tasks. Instructor, $101,23-24,26,28-29$.

Calkins, L.M. (1986, 1994). The art of teaching writing. Portsmouth, NH: Heinemann.

Calkins, L.M. \& Harwayne, S. (1991). Living between the lines, Portsmouth, NH: Heinemann.

Chapman, C. (1990). Authentic writing assessment, ERIC Document, \#ED328606. 
Cockrun, Ward A. \& Costillo, Maggie. (1991). Whole language assessment and evaluation strategies. In Bill Harp (Ed.), Assessment and Evaluation in Whole Language Programs (pp. 82-83). MA: Christopher-Gordan Publishers.

Collins, Jude. (1991, Spring). Kindest regards: Teacher response to pupil writing. Use of English, 42, 29-41.

Costa, A.L. (1989, April). Re-assessing assessment. Educational Leadership, 46.

DeFina, A.A. (1992). Pontfolio Assessment: Getting Started. N.Y.: Scholastic Professional Books.

DeGroff, Linda. (1992, Nov.) Process writing teachers' response to 4th grade writer's first drafts. Elementary School Journal, 93, 131-44.

Doll, W.E. (1993). Apost-modern perspective on curriculum, NY: Teachers College Press.

Edelsky, C.; Smith, K. (1984, Jan.) Is that writing-Or are those marks just a figment of your curriculum? Language Arts. 61, 24-32.

Farr, R. (1990). Setting directions for language arts portiolios, Educational Leadership, 43, 103.

Fernandez, E.; Baker, S. (1993). Assessment Pontfolios, Grade K-5. Two Way Spanish Partial Lmmersion Program. ERIC Document \#ED364079.

Flower, L. and Hayes, J.R. (1981). A cognitive process theory of writing. College Composition and Communication. 32, 365-387.

Gilles, Bixby, Crowley (Eds.)(1988). Whole lanquage strategies for secondary students, NY., NY: Richard C. Owen Publishers.

Goodman, K. \& Others (Eds.)(1989). The whole language evaluation book, Portsmouth, NH: Heinemann.

Graves, D.H. (1983). Writing: Teachers and children at work, Portsmouth, NH: Heinemann. 
Graves, D.H. (1984). Aresearcher learns te write, Portsmouth,NH: Heinemann.

Graves, D.H. (1985). All children can write. Learning Disabilities Focus, 1, 36-43.

Graves, D.H. (1994, Nov./Dec.). Writing workshop: Be a better writing teacher. Instructor, 104, 43-45,71.

Hamilton, A. (1992). Performance assessment of personal correspondance on the development of written language use and function in traditional and process writing in 2nd grade classrooms, ERIC Document \# ED354253.

Harp, B. (Ed.) (1991). Assessment and evaluation in whole language programs. Norwood, MA: Christopher-Gordon Publishing, Inc.

Hayes, C. (1990). Using Writing to promote reading to learn in college, ERIC Document \# ED322499,

Heald-Taylor, G. (1986). Whole language strategies for ESL students. Lanquage and Literacy Series, ERIC Document \#ED280287.

Hilgers, T. (1984, July). Toward a Taxonomy of Beginning Writer's Evaluative Statements on Written Composition. Written Communication, 1, 365-84.

Hilgers, T. (1986, Feb.). How children change as critical evaluators of writing: Four three-year case studies. Besearch in the Teaching of English, 20.

Hodges, R. (1977). In Adam's fall: A brief history of spelling instruction in the United States. In H. Robinson (Ed.), Reading and writing instruction in the United States: Historical trends (pp. 1-16). Neward, DE: International Reading Association.

Krest, M. (1990). Adapting the portfolio to meet student needs. English Journal, $79,29-34$

Lindaman, A. and Lewis, M. (1989, August). Writing instruction... American School Board Journal, 176, 17, 39.

Long, S.-Spaine (1992). Using the process model for writing:Options in responding to student drafts, ERIC Document \# ED352826. 
McCarthy, P.; Meier, S. and Rinderer, R. (1985, Dec.). Self-efficacy and writing: A different view of self-evaluation. College Composition and Communication, 36, 165-71.

McGinley, W. and Kamberelis, G. (1992). Transformative functions of children's writing. Lanquage Adts, 69, 330-338.

Manning, M. and Manning, G. (1995, Feb.). Portfolios in reading and writing. Teaching-Pre K-8, 25, 94-95.

Michaels, W. \& Karnes, M.R. (1950). Measuring educational achievement. NY: McGraw-Hill Book Company.

Miller, S. (1982). How writers evaluate their own writing. College Composition and Communication, $33,176-83$.

Nolan, T.E. (1991). Self-questioning and prediction: Combining metacognitive strategies. Journal of Reading, 35, 132-38.

Olson, M. (1991). Portfolio's: Educational tools. Reading Psychology, 12, 73-80.

Perrone, V. (1991, Spring). On standardized testing. Childhood Education, 67, $131-42$.

Reutzel, D.; Hollingsworth P. (1988, March). Whole Language and the Practitioner. Academic Therapy, 23, 405-16.

Rhodes, B. (1992). Extending the context of evaluation: Writing letters, not merely letter grades. ERIC Document \#ED345269.

Rief, L. (1990, March). Finding the value in evaluation: Self-assessment in a middle school class. Educational Leadership, 47, $24-29$.

Runyan, Y. (1991). Holistic assessment in intermediate classes: Techniques for informing our teaching. In Bill Harp (Ed.), Assessment and evaluation in whole language programs (pp. 111-114). Norwood, MA:

Christopher-Gordon Publishers. Inc. 
Ryan, J. \& Miyasaka, J. (1995, Oct.) Current practices in testing and assessment: What is driving the changes? NASSP Bulletin, 79, 1-10.

Ryan, T. (Ed.). (1993). Collaborative development of a cohesive, systematic writing evaluation made for grades 6-12. ERIC Document \#ED369078.

Samway, K.D. (1992). Writer's workshop and children acquiring English as a non-native language. Washington D.C.: National Clearinghouse for Bilingual Education.

Samway, K.D. (1993, March). This is hard, isn't it?: Children evaluating writing. IESOL Quarterly.

Scannell, D.P. \& Marshall, J.C. (1966). The effect of selected composition errors on grades assigned to essay examinations. American Educational Besearch Journal, 3, 125-130.

Schumacher, G. and Martin,D. (1983). Acategorical analysis of writing protocals of English school children, ERIC Document \#ED240578.

Searle, D. and Dillon, D. (1980a, October). Responding to student writing: What is said or how it is said. Lanquage Ants, 57.

Searle, D. and Dillon, D. (1980b, October). The message of marking: Teacher written responses to student writing at intermediate grade levels. Besearch in the Teaching of English, 14.

Shepard, L. (1989, April). Why we need better assessments. Educational Leadership, 46, 4-9.

Shor, I. (1992). Empowering education - Critical teaching for social change, The University of Chicago Press, Chicago.

Strech, L. (1994). Student-centered writer's workshop. Action research: The implications of writer's workshop in the third arade. ERIC Document \#ED380798.

Valencia, S. (1990). A portfolio approach to classroom assessment: The why, whats and hows. The Reading Teacher, 43, 338-40. 
Ziv, N. (1980). The effect of teacher comments on the writing of four college freshmen, ERIC Document \#ED203317. 
Appondix 


\section{Table 1}

Essay Grade Checklist

Student

Essay Title

1. The essay focuses on a particular subject.
Range Score:
$0 . .10$
Points:

2. The essay has appropriate beginning, middle, and ending sections.
Range Score:
$0 . .10$
Points:

3. The sequence of events is logical.
Range Score:
0 .. 10
Points:

4. The essay maintains its voice (first person or third person).
Range Score:
$0 . .10$
Points:

5. Verb tense and agreement are appropriately used.
Range Score:
$0 . .10$
Points:

6. The essay is written using complete sentences.
Range Score:
$0 . .10$
Points:

7. The essay contains appropriate descriptive language.
Range Score:
$0 . .10$
Points:

8. The essay is correctly punctuated.
Range Score:
$0 . .10$
Points:

9. The essay uses rules of capitalization.
Range Score:
$0 . .10$
Points:

10. The essay has been proofread for spelling errors.
Range Score:
$0 . .10$
Points:

Total points for the essay:

Defina, A. A. (1992). Penffolie Assessment: Getting Started. N.Y.: Scholastic Professional Books. 
Table 2

Writing Sample Interview Prompts

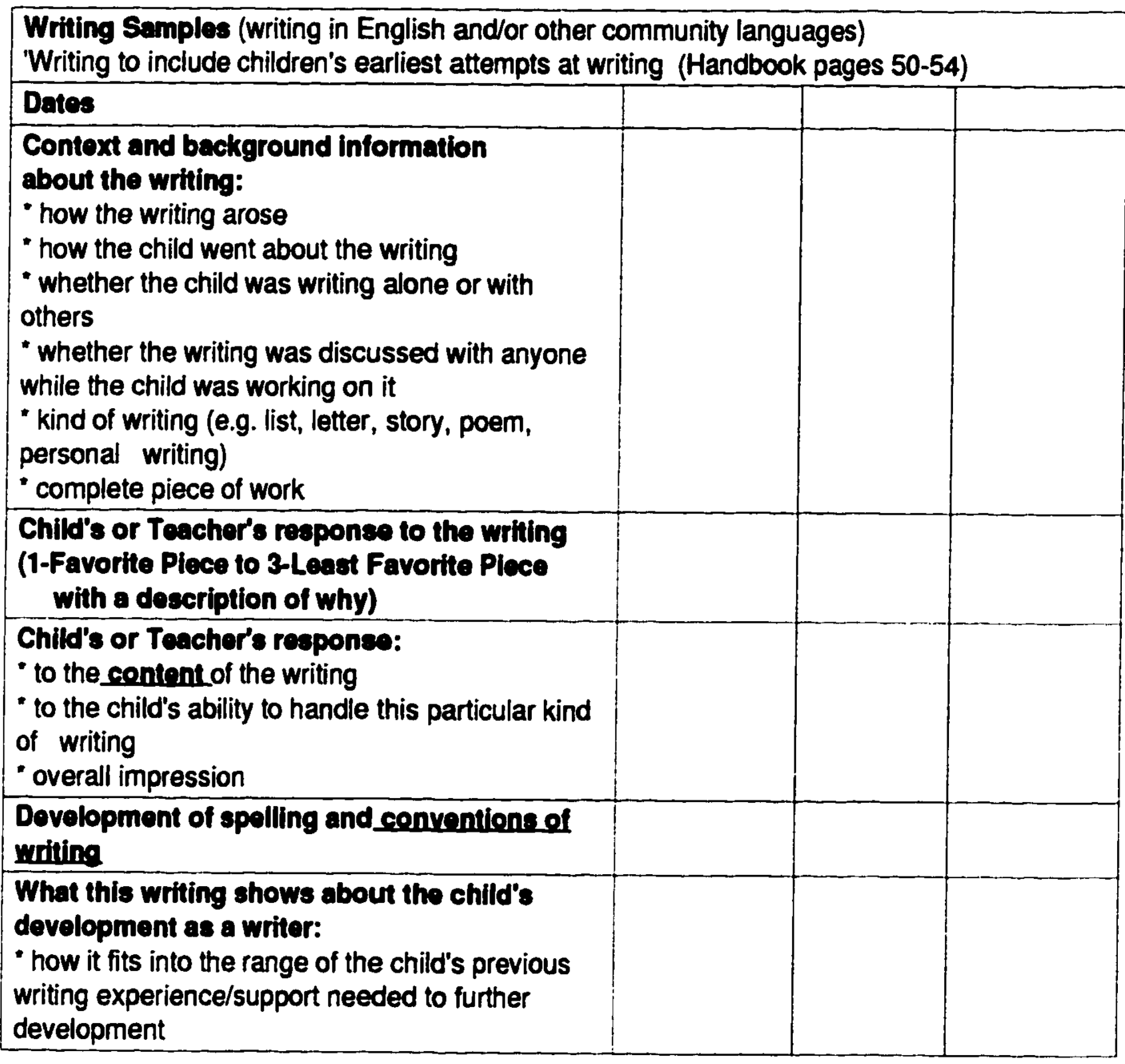

Barrs, M.; Ellis,S.; Hester, H. \& Thomas, A. (1988). Inner London Education Authority (ILEA), Center for Primary Education. The orimary lanquace record: Handbook for teachers. Portsmouth, NH: Heinemann. 
Table 3

Writing Survey

1. Are you a writer?

(If your answer is YES, answer question $2 a$. If your answer is NO, answer 2b.)

2a. How did you learn to write?

2b. How do people learn to write?

3. Why do people write?

4. What do you think a good writer needs to do in order to write well?

5. How does your teacher decide which pieces of writing are the good ones?

6. In general, how do you feel about what you write?

Atwell, N. (1987). In the middle: Writing reading and learning with adolescents. Portsmouth, $\mathrm{NH}$ : Boynton/Cook. 
Table 4

Evaluative Comments: A Comparison of Students

\begin{tabular}{|c|c|c|c|c|c|c|c|c|c|c|}
\hline Rosponder & Total & $\begin{array}{l}\text { Value } \\
\text { Roluted }\end{array}$ & Crafting & Machanics & Lling & Entertainmont & Organization & $\begin{array}{l}\text { Riak } \\
\text { Toling }\end{array}$ & $\begin{array}{l}\text { Miscollanoou } \\
\text { s }\end{array}$ & $\begin{array}{l}\text { No } \\
\text { Gromth }\end{array}$ \\
\hline \multirow[t]{2}{*}{ Robart } & 13 & 2 & 4 & 1 & 4 & 1 & & 1 & & \\
\hline & & $15 \%$ & $31 x_{0}$ & $8 x$ & $31 \%$ & $8 \%$ & $0 x$ & $8 x$ & $0 \%$ & $0 x$ \\
\hline \multirow[t]{2}{*}{ Brett } & 9 & & 2 & 2 & 3 & & & 1 & & 1 \\
\hline & & $0 x$ & $22 \%$ & $22 \%$ & $33 \%$ & $0 \times$ & $0 \%$ & $11 \%$ & $0 x$ & $11 x_{0}$ \\
\hline \multirow[t]{2}{*}{ Cindy } & 10 & 2 & 1 & 9 & 1 & 4 & 1 & & & \\
\hline & & $20 \%$ & $10 x$ & $10 \%$ & $10 \%$ & $40 \%$ & $10 x$ & $0 \%$ & $0 \%$ & $0 \%$ \\
\hline \multirow[t]{2}{*}{ Nina } & 13 & 1 & & 3 & 3 & 3 & $i$ & 1 & 1 & \\
\hline & & $8 \bar{x}$ & $0 x$ & 2376 & $23 \%$ & $23 \%$ & $8 \%$ & $8 \%$ & $8 \%$ & $0 x_{0}$ \\
\hline \multirow[t]{2}{*}{ Conner } & 11 & 4 & 1 & 1 & 2 & & & 1 & 1 & 1 \\
\hline & & $36 \%$ & $8 x$ & $9 \%$ & $18 \%$ & $0 \%$ & $0 \%$ & $8 \%$ & $8 \%$ & $9 \%$ \\
\hline \multirow[t]{2}{*}{ Ashion } & 11 & & 4 & 2 & 2 & & & 1 & & 2 \\
\hline & & $0 \%$ & $36 \%$ & $18 \%$ & $18 \%$ & $0 \%$ & $0 x$ & $8 x_{6}$ & $0 x_{0}$ & $18 \%$ \\
\hline \multirow[t]{2}{*}{ Amanda } & 11 & & 1 & 4 & 2 & & & 3 & 1 & \\
\hline & & $0 x$ & $9 x$ & $36 \%$ & $18 x_{0}$ & $0 \%$ & $0 x$ & $27 \%$ & $9 \%$ & $0 \%$ \\
\hline \multirow[t]{2}{*}{ Codric } & 11 & 1 & 3 & 1 & 1 & & 1 & 3 & & 1 \\
\hline & & $9 \%$ & $27 \%$ & $9 \%$ & $9 \%$ & $0 \%$ & 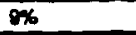 & $27 \%$ & $0 x_{0}$ & $9 \%$ \\
\hline \multirow[t]{2}{*}{ Char } & 14 & 2 & 2 & 2 & 5 & & & 2 & 1 & \\
\hline & & $14 \%$ & $14 x$ & 104 & $36 \%$ & $0 \%$ & $0 \%$ & $14 \%$ & $7 \%$ & $0 \%$ \\
\hline \multirow[t]{2}{*}{ Kon } & 9 & & 3 & 1 & 2 & 1 & & 2 & & \\
\hline & & $0 x$ & $33 \%$ & $11 x$ & $22 \%$ & $11 \%$ & $0 \%$ & $22 x$ & $0 x$ & $O H$ \\
\hline \multirow[t]{2}{*}{ Totals } & 112 & 12 & 21 & 18 & 25 & 9 & 3 & 15 & 4 & 5 \\
\hline & & $11 \%$ & $19 x$ & $16 \%$ & $22 \%$ & $8 x$ & $3 \%$ & $13 \%$ & $4 \%$ & $4 \%$ \\
\hline
\end{tabular}


Table 5

\section{Evaluative Comments: A Comparison of each Student and the Teacher}

\begin{tabular}{|c|c|c|c|c|c|c|c|c|c|c|}
\hline Respondar & Total & $\begin{array}{l}\text { Vatuo } \\
\text { Ralated }\end{array}$ & Crafting & Mechanics & Lking & Entertainmont & Organization & $\begin{array}{l}\text { Risk } \\
\text { Teting }\end{array}$ & Miscollanoous & $\begin{array}{l}\text { No } \\
\text { Gromh }\end{array}$ \\
\hline \multirow[t]{2}{*}{ Robant } & 13 & 2 & 4 & 1 & 4 & 1 & & 1 & & \\
\hline & & $15 \%$ & $31 \%$ & $8 \%$ & $31 \%$ & $8 \%$ & $0 \%$ & $8 \%$ & $0 \%$ & $0 \%$ \\
\hline \multirow{2}{*}{ Teachor } & 12 & 1 & 6 & 1 & & 1 & 3 & & & \\
\hline & & $8 \%$ & $50 \%$ & $8 \%$ & $0 \%$ & $8 \%$ & $25 \%$ & $0 \%$ & $0 \%$ & $0 \%$ \\
\hline \multirow[t]{2}{*}{ Brott } & 8 & & 2 & 2 & 3 & & & 1 & & 1 \\
\hline & & $0 \%$ & $22 \%$ & $22 x$ & $33 \%$ & $0 \%$ & $0 \%$ & $11 \%$ & $0 \%$ & $11 \%$ \\
\hline \multirow{2}{*}{ Toacher } & 10 & & 7 & & & & 2 & 1 & & \\
\hline & & $0 \%$ & $70 \%$ & $0 \%$ & $0 \%$ & $0 \%$ & $20 \%$ & $10 \%$ & $0 \%$ & $\infty x_{0}$ \\
\hline \multirow[t]{2}{*}{ Cindy } & 10 & 2 & 1 & $t$ & 1 & 4 & 1 & & & \\
\hline & & $20 \%$ & $10 \%$ & $10 \%$ & $10 \%$ & $10 \%$ & 1086 & $0 \%$ & $0 \%$ & $0 \%$ \\
\hline \multirow[t]{2}{*}{ Teachar } & 8 & & 3 & 1 & & & $t$ & & 1 & 2 \\
\hline & & 0 & $38 \%$ & $13 \%$ & $0 \%$ & $0 \%$ & $13 \%$ & $0 \%$ & $13 \%$ & $25 \%$ \\
\hline \multirow[t]{2}{*}{ Nina } & 13 & 1 & & 3 & 3 & 3 & 1 & 1 & 1 & \\
\hline & & $8 \%$ & $0 \%$ & $23 \%$ & $23 \%$ & $23 \%$ & $8 \%$ & $8 \%$ & $8 \%$ & $0 \%$ \\
\hline \multirow[t]{2}{*}{ Toacher } & 14 & & 7 & 5 & & & 2 & & & \\
\hline & & $0 \%$ & $50 \%$ & $36 \%$ & $0 \%$ & $0 \%$ & $14 \%$ & $0 \%$ & $0 \%$ & $0 \%$ \\
\hline \multirow[t]{2}{*}{ Connor } & 11 & 4 & 1 & 1 & 2 & & & 1 & 1 & 1 \\
\hline & & $36 \%$ & $9 \%$ & 96 & $18 \%$ & $0 \%$ & $0 \%$ & $9 \%$ & $8 \%$ & $9 x$ \\
\hline \multirow[t]{2}{*}{ Toschor } & 9 & & 6 & 2 & & & & & & 1 \\
\hline & & $0 \%$ & $67 \%$ & $22 \%$ & $0 \%$ & $0 \%$ & $0 \%$ & $O x$ & $0 \%$ & $11 \%$ \\
\hline \multirow[t]{2}{*}{ Ashion } & 11 & & 4 & 2 & 2 & & & 1 & & 2 \\
\hline & & $0 \%$ & $36 \%$ & $18 \%$ & $18 \%$ & $0 \%$ & $0 \%$ & $9 x$ & $0 \%$ & $18 \%$ \\
\hline \multirow[t]{2}{*}{ Toacher } & 9 & & 3 & 3 & & & & 1 & 1 & 1 \\
\hline & & $0 \%$ & $33 \%$ & $33 \%$ & $0 \%$ & $0 \%$ & $0 \%$ & $11 \%$ & $11 \%$ & $11 \%$ \\
\hline \multirow[t]{2}{*}{ Arranda } & 11 & & 1 & 4 & 2 & & & 3 & 1 & \\
\hline & & $0 \%$ & $9 \%$ & $36 \%$ & $18 \%$ & $0 \%$ & $0 \%$ & $27 \%$ & $9 \%$ & $\infty x_{0}$ \\
\hline \multirow[t]{2}{*}{ Toachor } & 14 & & 11 & & & & 1 & 1 & & 1 \\
\hline & & $0 \%$ & $70 \%$ & $a x$ & $a x_{0}$ & $0 x$ & $7 \%$ & $7 \%$ & $0 \%$ & $7 x$ \\
\hline \multirow[t]{2}{*}{ Codine } & 11 & 1 & 3 & 1 & 1 & & 1 & 3 & & 1 \\
\hline & & $9 x$ & $27 \%$ & $8 \%$ & $8 \%$ & $0 \%$ & $9 \%$ & $27 \%$ & $0 \%$ & $8 \%$ \\
\hline \multirow[t]{2}{*}{ Touchar } & 10 & & 6 & & & & 1 & & 1 & 2 \\
\hline & & $0 \%$ & $60 \%$ & $a x$ & $0 \%$ & $0 \%$ & $10 \%$ & $0 \%$ & $10 \%$ & $20 \%$ \\
\hline \multirow[t]{2}{*}{ Char } & 14 & 2 & 2 & 2 & 5 & & & 2 & 1 & \\
\hline & & $14 \pi$ & $14 \%$ & $14 \%$ & $36 \%$ & $0 \%$ & $0 \%$ & $16 \%$ & $7 \%$ & $0 \%$ \\
\hline \multirow[t]{2}{*}{ Toachor } & 16 & & 10 & 3 & 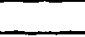 & & 3 & & & \\
\hline & & $0 \%$ & $63 \%$ & $19 \%$ & $0 \%$ & $0 x$ & $10 \%$ & $0 x$ & $0 \%$ & $0 \%$ \\
\hline \multirow[t]{2}{*}{ Kon } & 9 & & 3 & 1 & 2 & 1 & & 2 & & \\
\hline & & $0 x$ & $33 \%$ & $11 \%$ & $22 \%$ & $11 \%$ & $0 \%$ & $22 \%$ & $0 x$ & $0 \%$ \\
\hline \multirow[t]{2}{*}{ Toachor } & 10 & 1 & 2 & 2 & 1 & 2 & & & & 2 \\
\hline & & $10 \%$ & $20 \%$ & $20 \%$ & $10 \%$ & $20 \%$ & $\alpha$ & $0 \%$ & $0 \%$ & $20 \%$ \\
\hline Sludents-Tolals & 112 & 12 & 21 & 18 & 25 & 8 & 3 & 15 & 4 & 5 \\
\hline & & $11 x$ & $10 x$ & $16 \%$ & $22 \%$ & $8 \%$ & $3 \%$ & $13 \%$ & $4 \%$ & $4 \%$ \\
\hline Teechor-Totals & 112 & 2 & 61 & 17 & 1 & 3 & 13 & 3 & 3 & 9 \\
\hline & & $2 \%$ & $54 \%$ & $15 \%$ & $1 \%$ & $3 \%$ & $12 \%$ & $3 \%$ & $3 \%$ & $8 \%$ \\
\hline Tolals & 224 & 14 & 82 & 35 & 26 & 12 & 16 & 18 & 7 & 14 \\
\hline & & $6 \%$ & $37 \%$ & $16 \%$ & $12 x$ & $5 \%$ & $7 \%$ & $8 \%$ & $3 \times$ & $6 \%$ \\
\hline
\end{tabular}


Table 6

Evaluative Comments: A Comparison of All Students and the Teacher

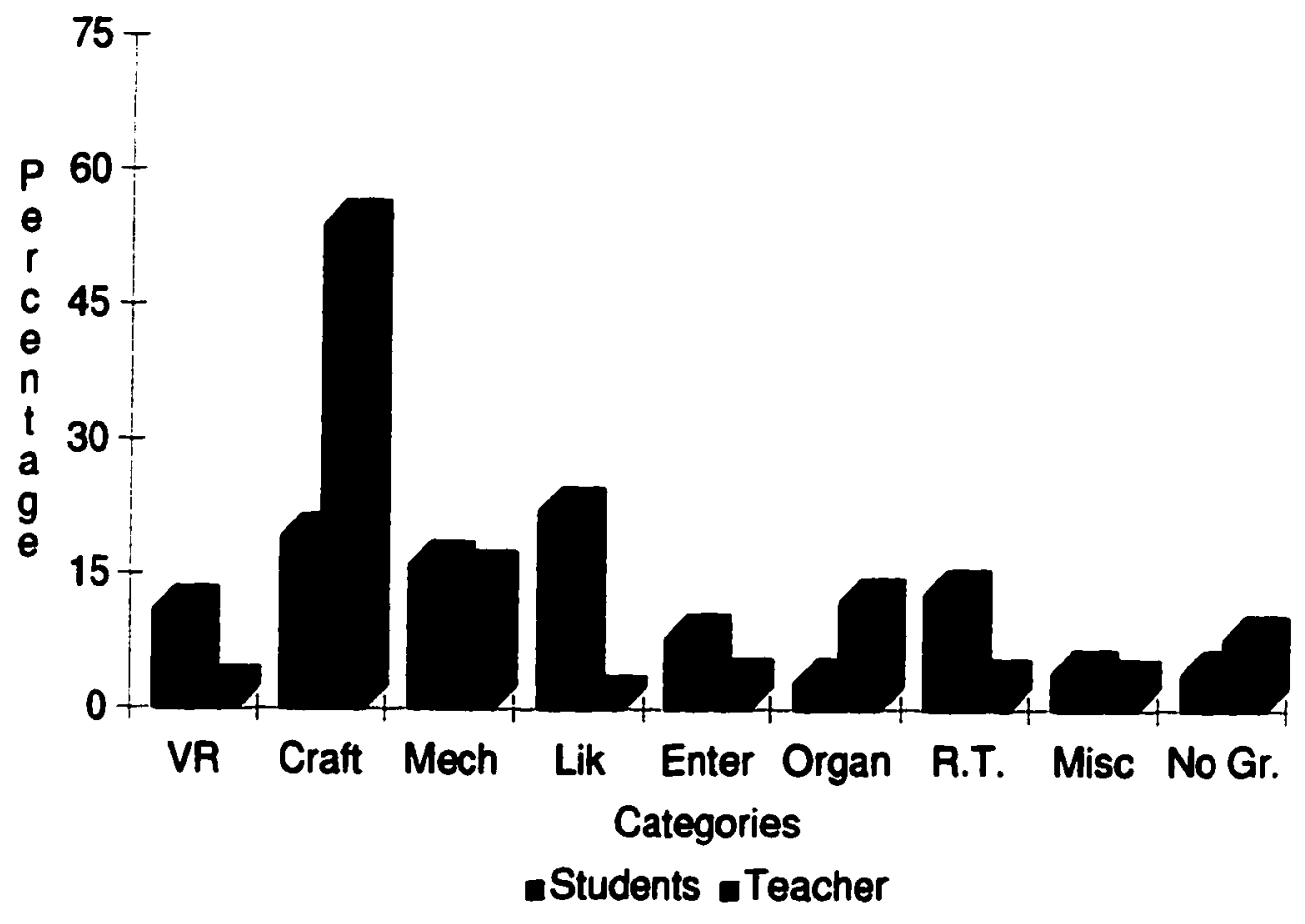

Key

\begin{tabular}{|l|l|}
\hline $\begin{array}{l}\text { Category } \\
\text { Abbreviation }\end{array}$ & Category \\
\hline VR & Value-Related \\
\hline Craft & Crafting \\
\hline Mech & Mechanics \\
\hline Lik & Liking \\
\hline Enter & Entertainment \\
\hline Organ & Organization \\
\hline R.T. & Risk-Taking \\
\hline Misc & Miscellaneous \\
\hline No Gr. & No Growth \\
\hline
\end{tabular}


Table 7

\section{Evaluative Comments: Ashton and theTeacher}

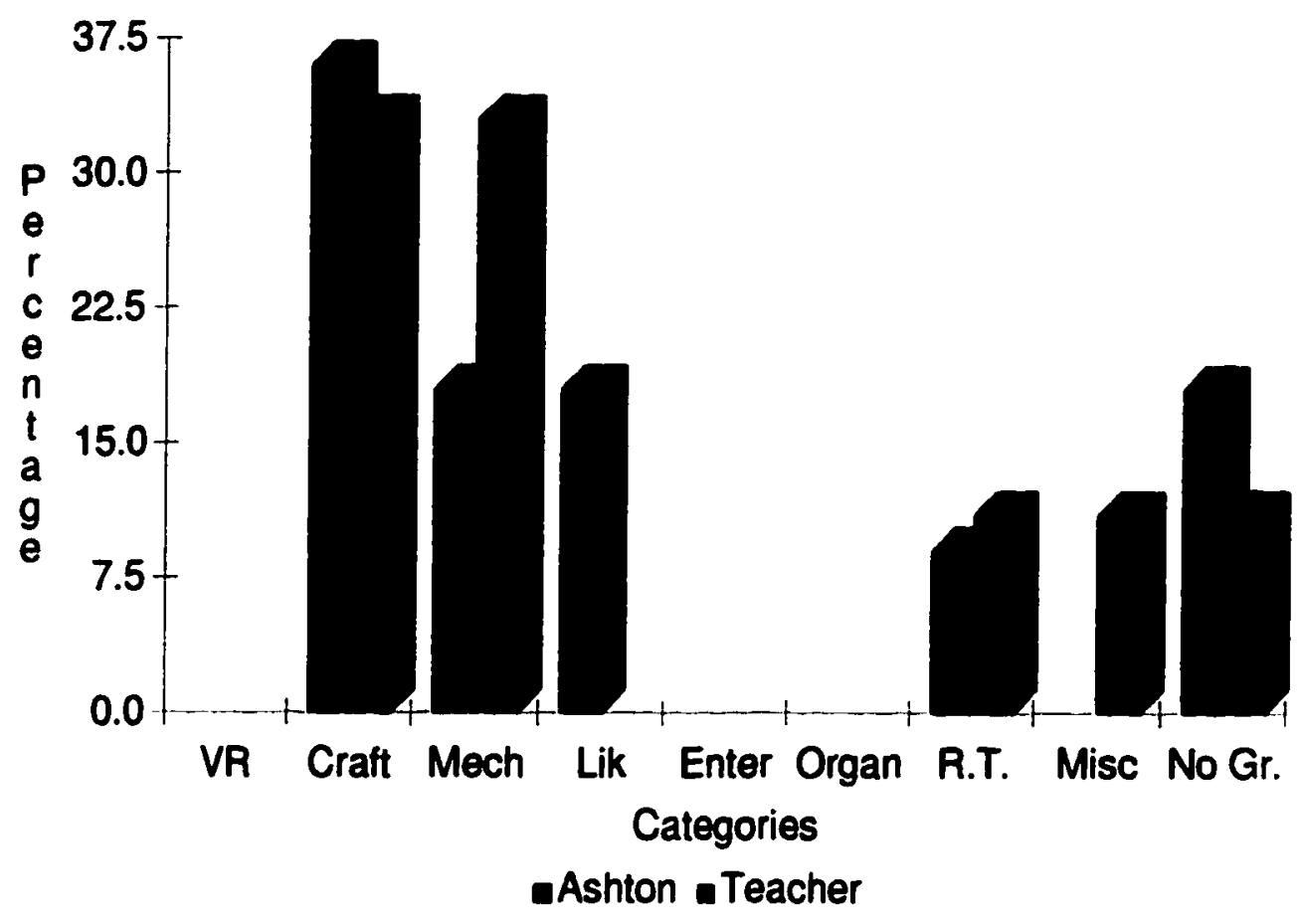

Key

\begin{tabular}{|l|l|}
\hline $\begin{array}{l}\text { Category } \\
\text { Abbreviation }\end{array}$ & Category \\
\hline VR & Value-Related \\
\hline Craft & Crafting \\
\hline Mech & Mechanics \\
\hline Lik & Liking \\
\hline Enter & Entertainment \\
\hline Organ & Organization \\
\hline R.T. & Risk-Taking \\
\hline Misc & Miscellaneous \\
\hline No Gr. & No Growth \\
\hline
\end{tabular}


Table 8

Evaluative Comments: Cedric and the Teacher

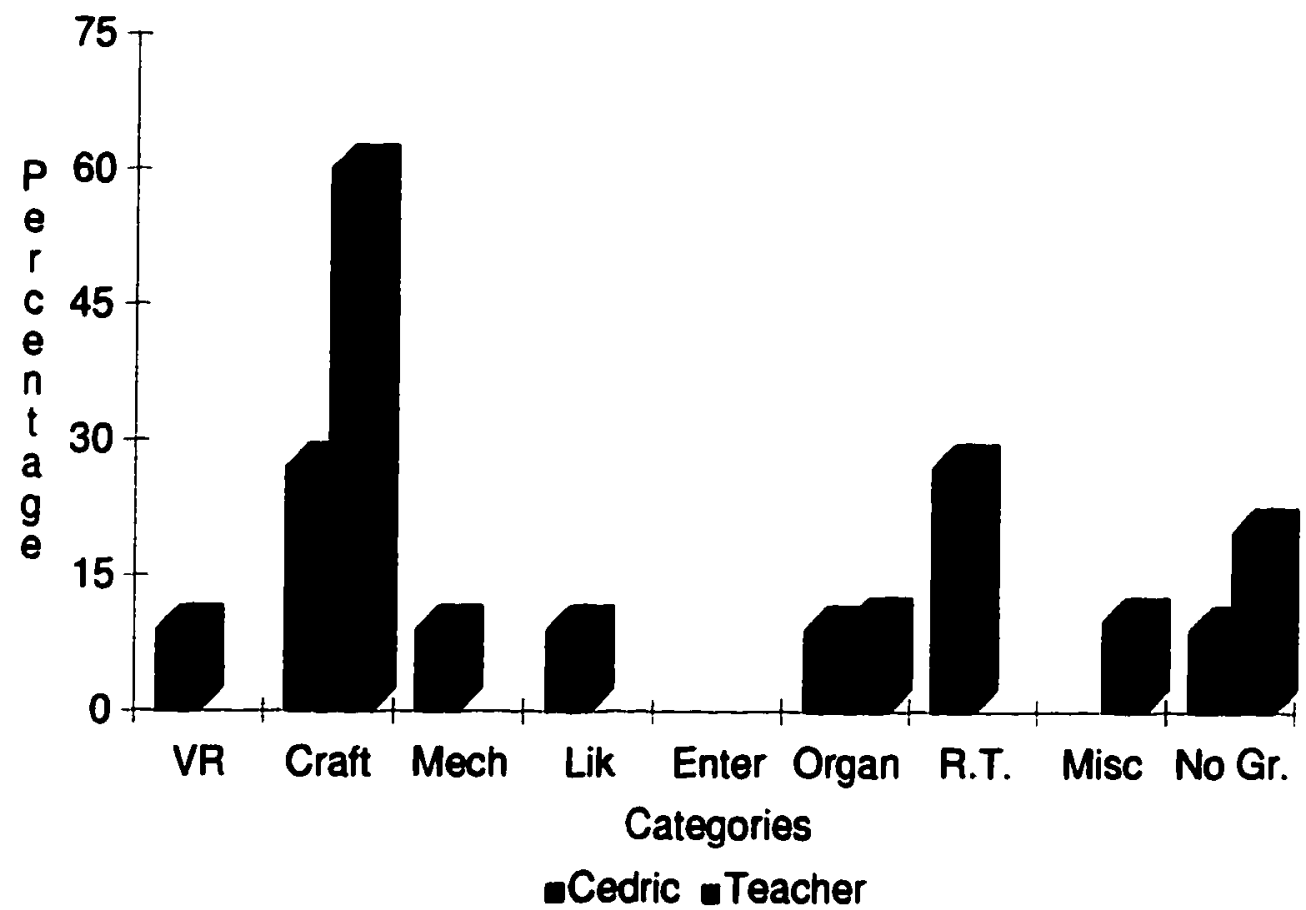

Key

\begin{tabular}{|l|l|}
\hline $\begin{array}{l}\text { Category } \\
\text { Abbreviation }\end{array}$ & Category \\
\hline VR & Value-Pelated \\
\hline Craft & Crafting \\
\hline Mech & Mechanics \\
\hline Lik & Liking \\
\hline Enter & Entertainment \\
\hline Organ & Organization \\
\hline R.T. & Risk-Taking \\
\hline Misc & Miscellaneous \\
\hline No Gr. & No Growth \\
\hline
\end{tabular}


Table 9

Evaluative Comments: Char and the Teacher

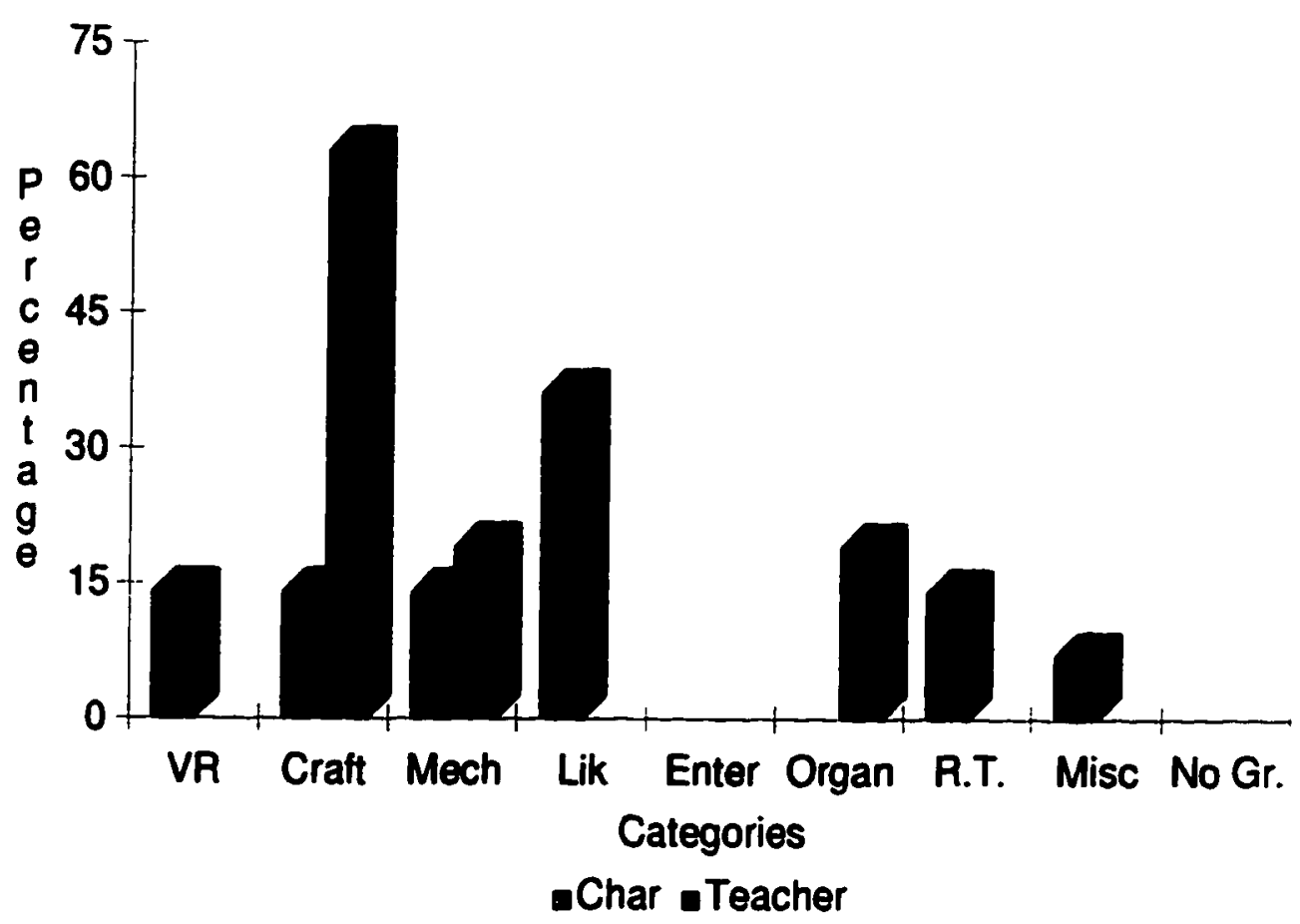

Key

\begin{tabular}{|l|l|}
\hline $\begin{array}{l}\text { Category } \\
\text { Abbreviation }\end{array}$ & Category \\
\hline VR & Value-Related \\
\hline Craft & Crafting \\
\hline Mech & Mechanics \\
\hline Lik & Liking \\
\hline Enter & Entertainment \\
\hline Organ & Organization \\
\hline R.T. & Risk-Taking \\
\hline Misc & Miscellaneous \\
\hline No Gr. & No Growth \\
\hline
\end{tabular}


Table 10

Evaluative Comments: Connor and the Teacher

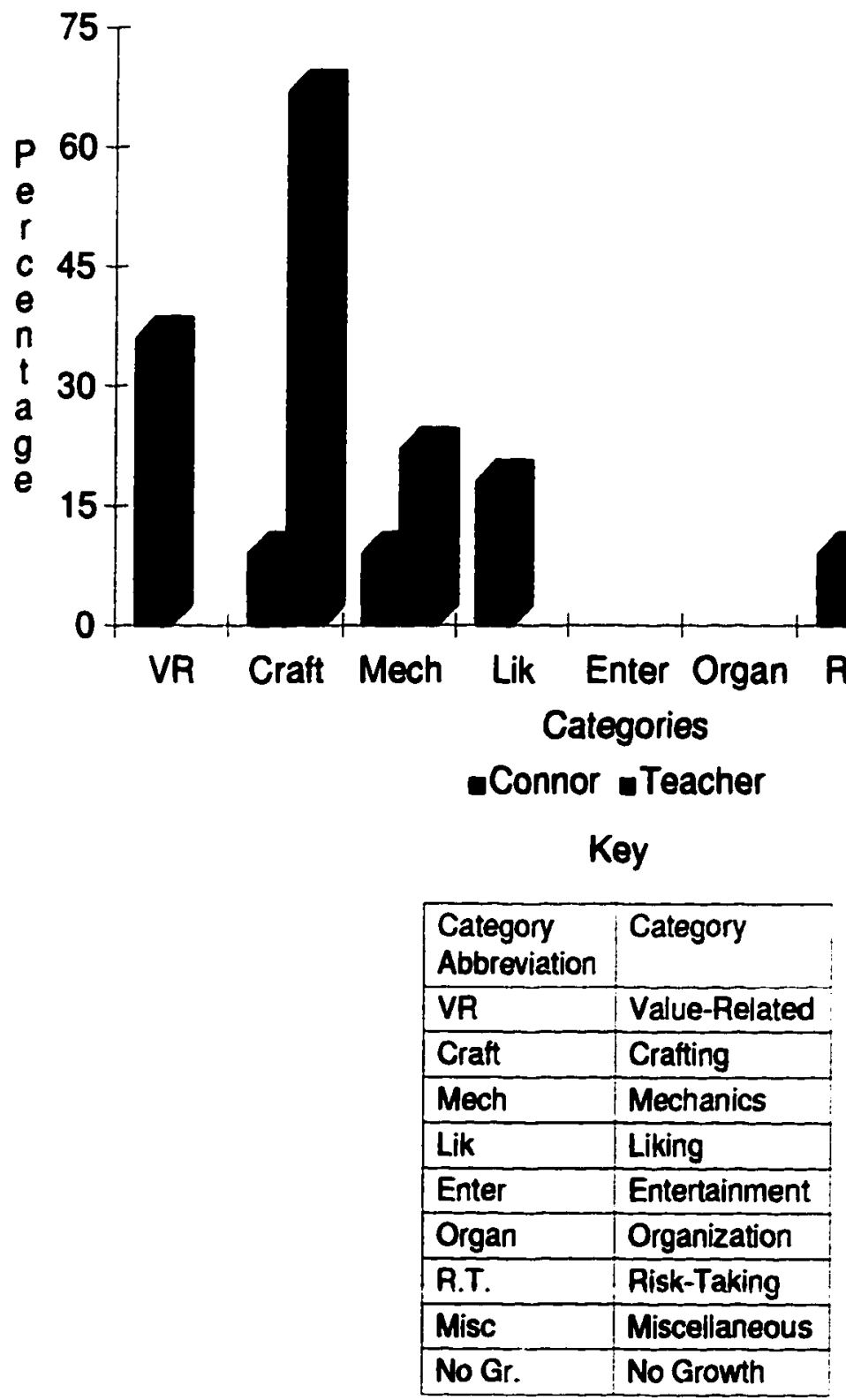


Table 11

Evaluative Comments: Ken and the Teacher

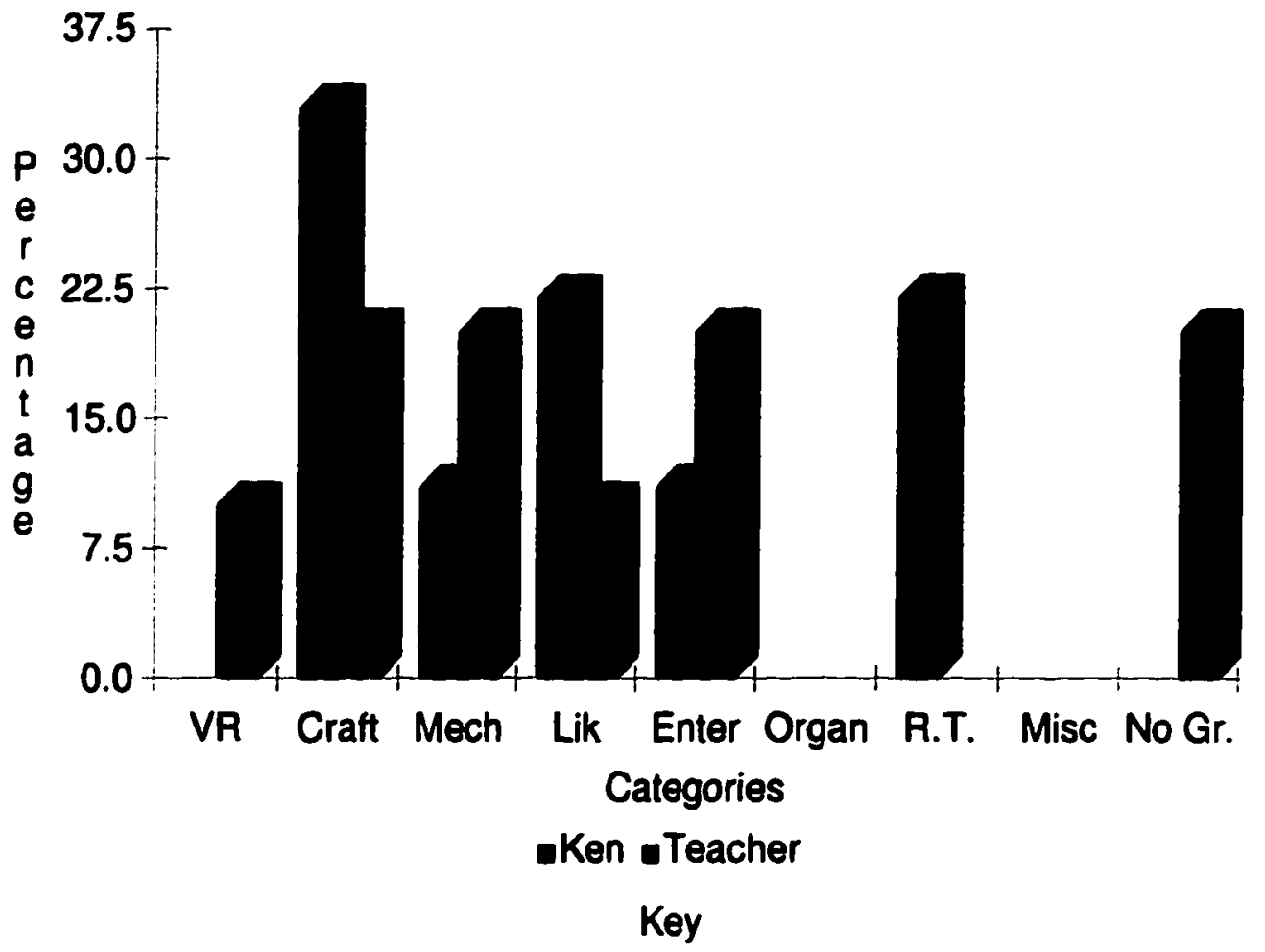

\begin{tabular}{|l|l|}
\hline $\begin{array}{l}\text { Category } \\
\text { Abbreviation }\end{array}$ & Category \\
\hline VR & Value-Related \\
\hline Craft & Crafting \\
\hline Mech & Mechanics \\
\hline Lik & Liking \\
\hline Enter & Entertainment \\
\hline Organ & Organization \\
\hline R.T. & Risk-Taking \\
\hline Misc & Miscellaneous \\
\hline No Gr. & No Growth \\
\hline
\end{tabular}


Table 12

Evaluative Comments: Robert and the Teacher

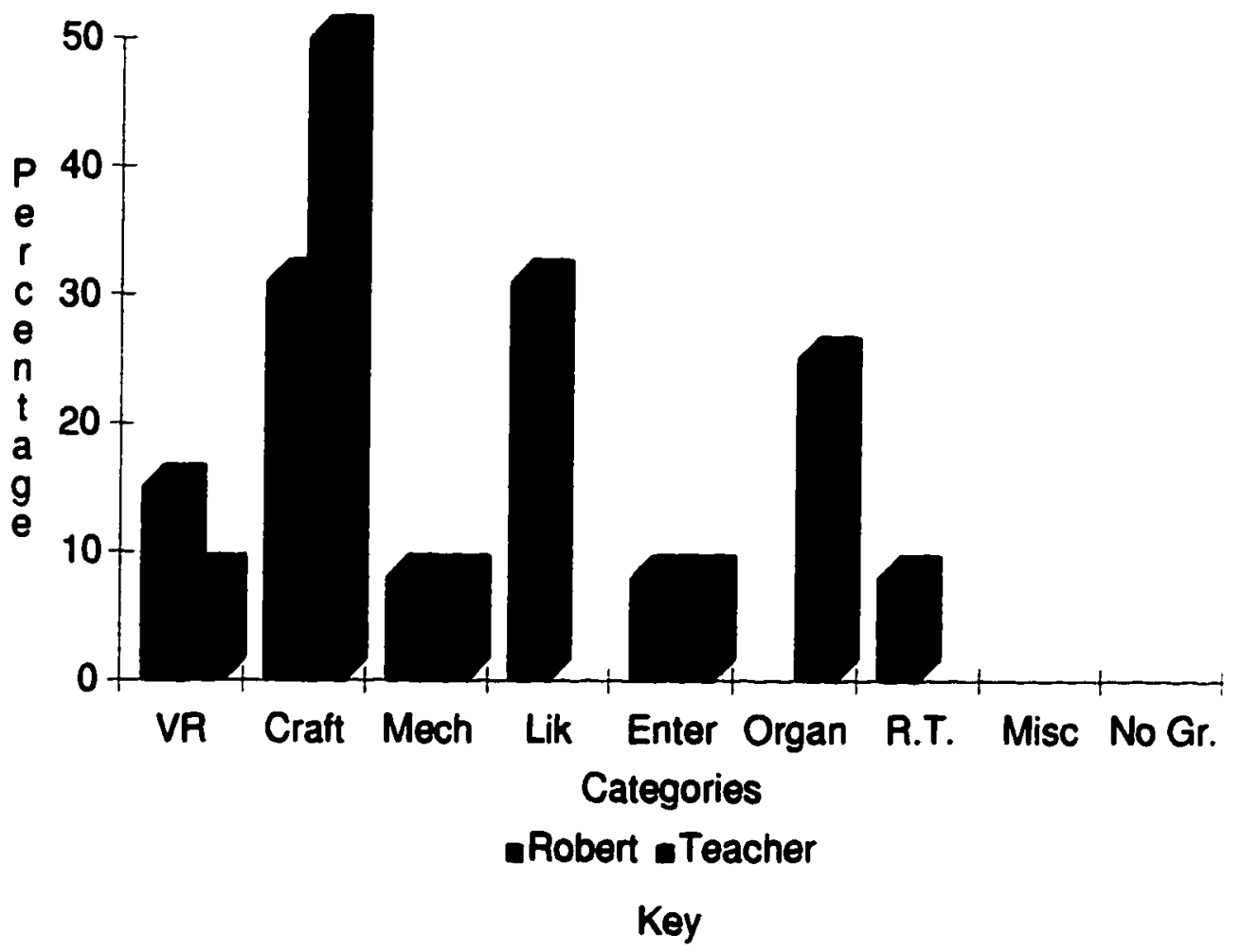

\begin{tabular}{|l|l|}
\hline $\begin{array}{l}\text { Category } \\
\text { Abbreviation }\end{array}$ & Category \\
\hline VR & Value-Related \\
\hline Craft & Crafting \\
\hline Mech & Mechanics \\
\hline Lik & Liking \\
\hline Enter & Entertainment \\
\hline Organ & Organization \\
\hline R.T. & Risk-Taking \\
\hline Misc & Miscellaneous \\
\hline No Gr. & No Growth \\
\hline
\end{tabular}


Table 13

Evaluative Comments: Amanda and the Teacher

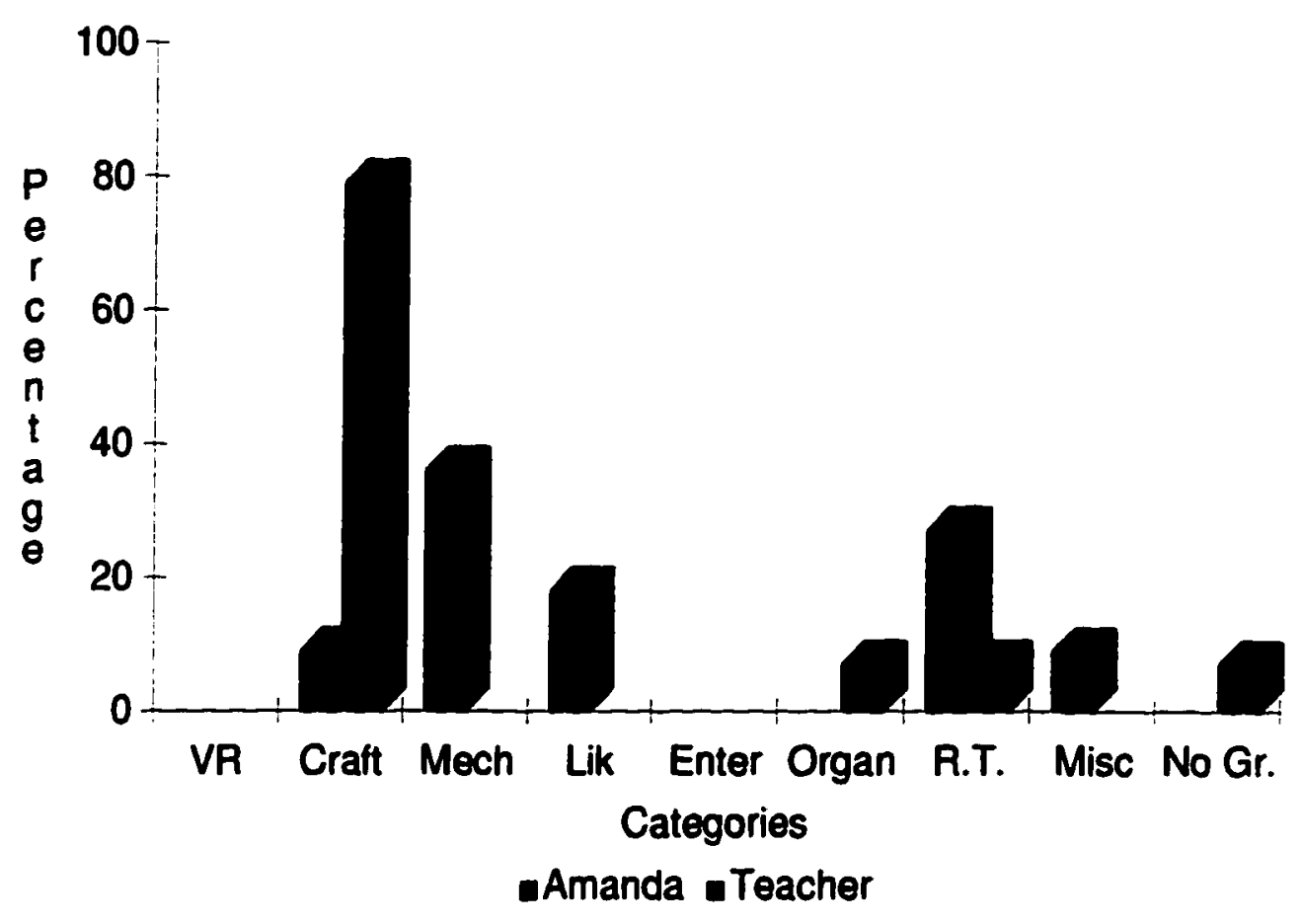

Key

\begin{tabular}{|l|l|}
\hline $\begin{array}{l}\text { Category } \\
\text { Abbreviation }\end{array}$ & Category \\
\hline VR & Value-Related \\
\hline Craft & Crafting \\
\hline Mech & Mechanics \\
\hline Lik & Liking \\
\hline Enter & Entertainment \\
\hline Organ & Organization \\
\hline R.T. & Risk-Taking \\
\hline Misc & Miscellaneous \\
\hline No Gr. & No Growth \\
\hline
\end{tabular}


Table 14

Evaluative Comments: Nina and the Teacher

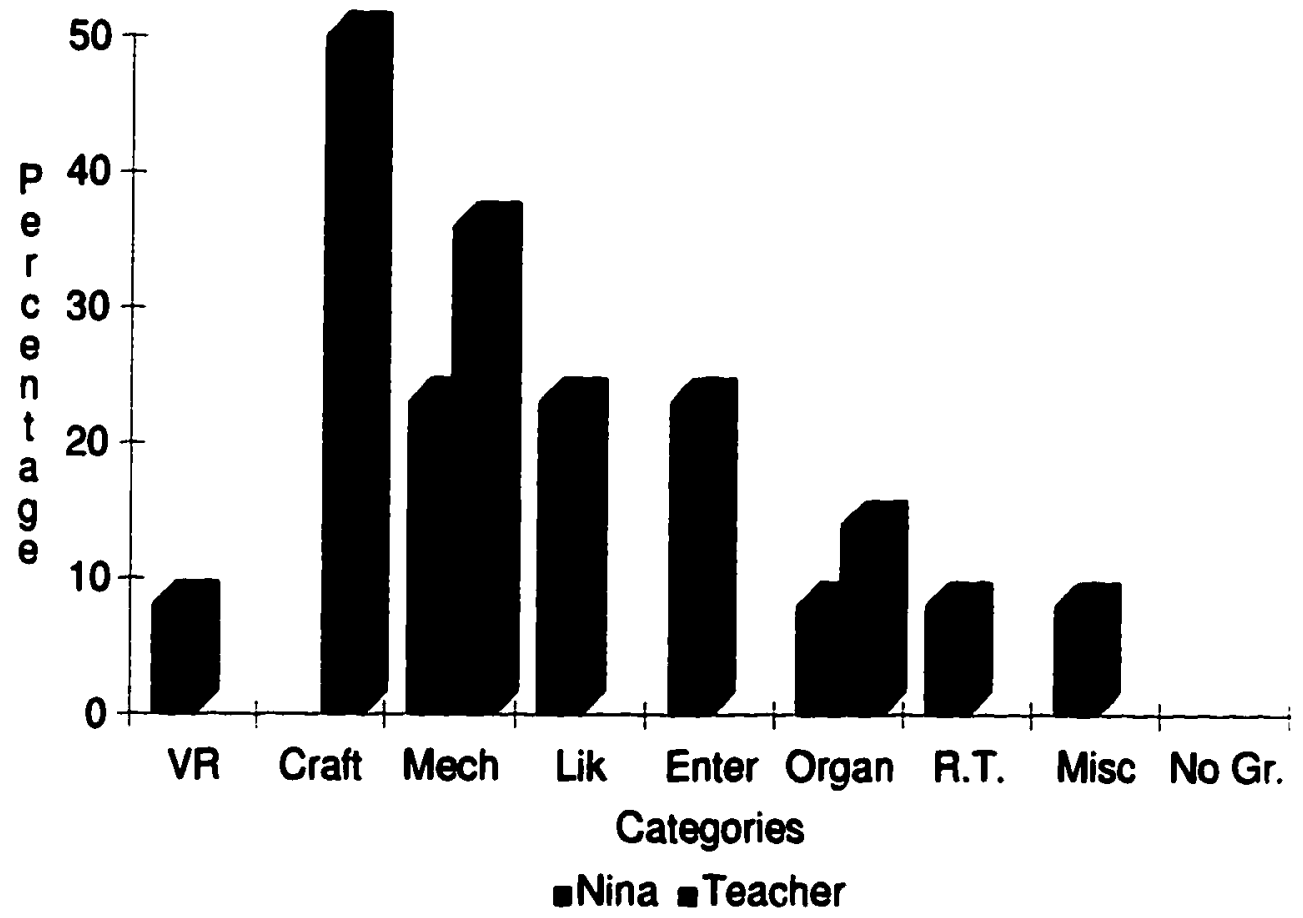

Key

\begin{tabular}{|l|l|}
\hline $\begin{array}{l}\text { Category } \\
\text { Abbreviation }\end{array}$ & Category \\
\hline VR & Value-Related \\
\hline Craft & Crafting \\
\hline Mech & Mechanics \\
\hline Lik & Liking \\
\hline Enter & Entertainment \\
\hline Organ & Organization \\
\hline R.T. & Risk-Taking \\
\hline Misc & Miscellaneous \\
\hline No Gr. & No Growth \\
\hline
\end{tabular}


Table 15

Evaluative Comments: Cindy and the Teacher

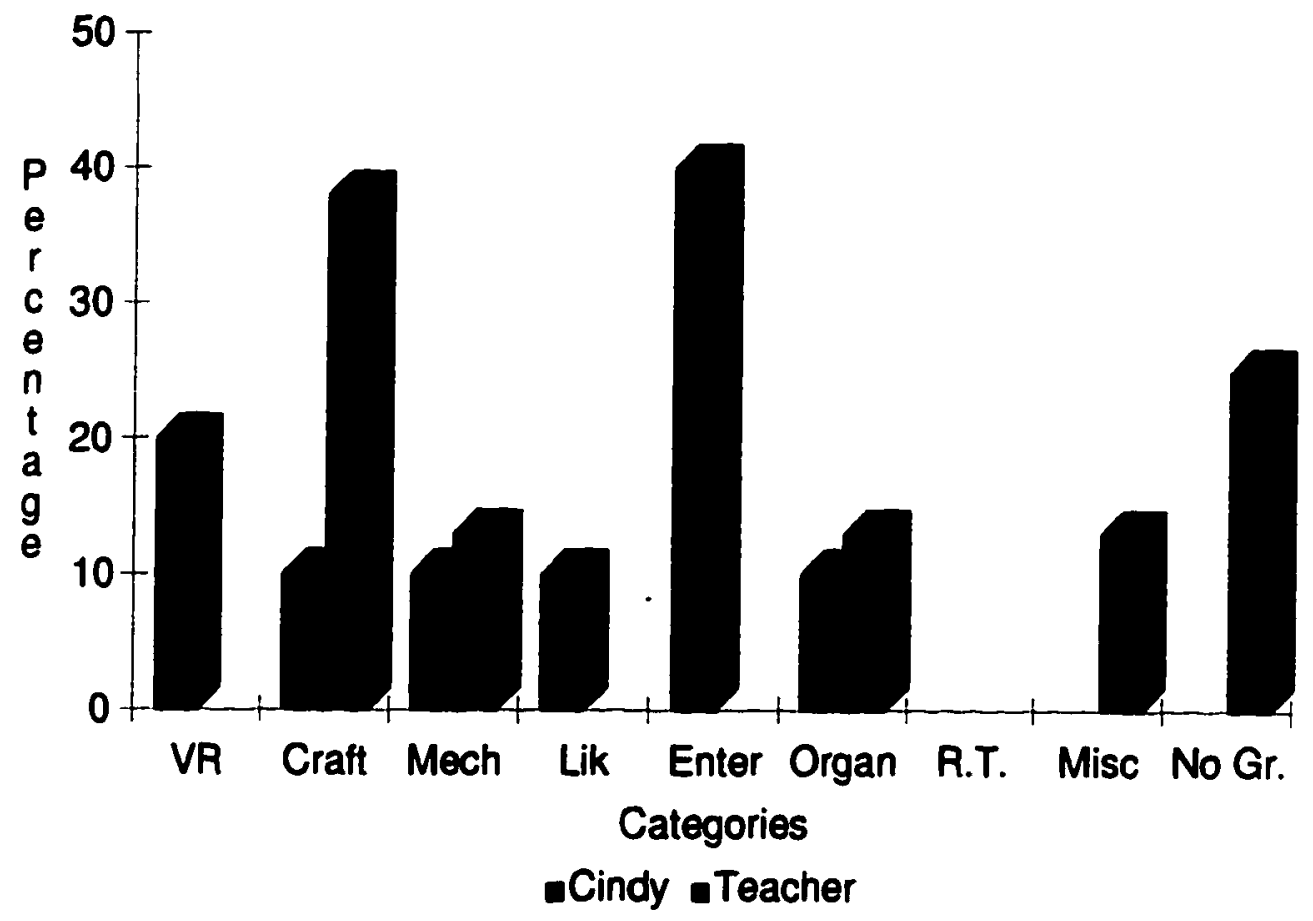

Key

\begin{tabular}{|l|l|}
\hline $\begin{array}{l}\text { Category } \\
\text { Abbreviation }\end{array}$ & Category \\
\hline VR & Value-Related \\
\hline Craft & Crafting \\
\hline Mech & Mechanics \\
\hline Lik & Liking \\
\hline Enter & Entertainment \\
\hline Organ & Organization \\
\hline R.T. & Risk-Taking \\
\hline Misc & Miscellaneous \\
\hline No Gr. & No Growth \\
\hline
\end{tabular}


Table 16

Evaluative Comments: Brett and the Teacher

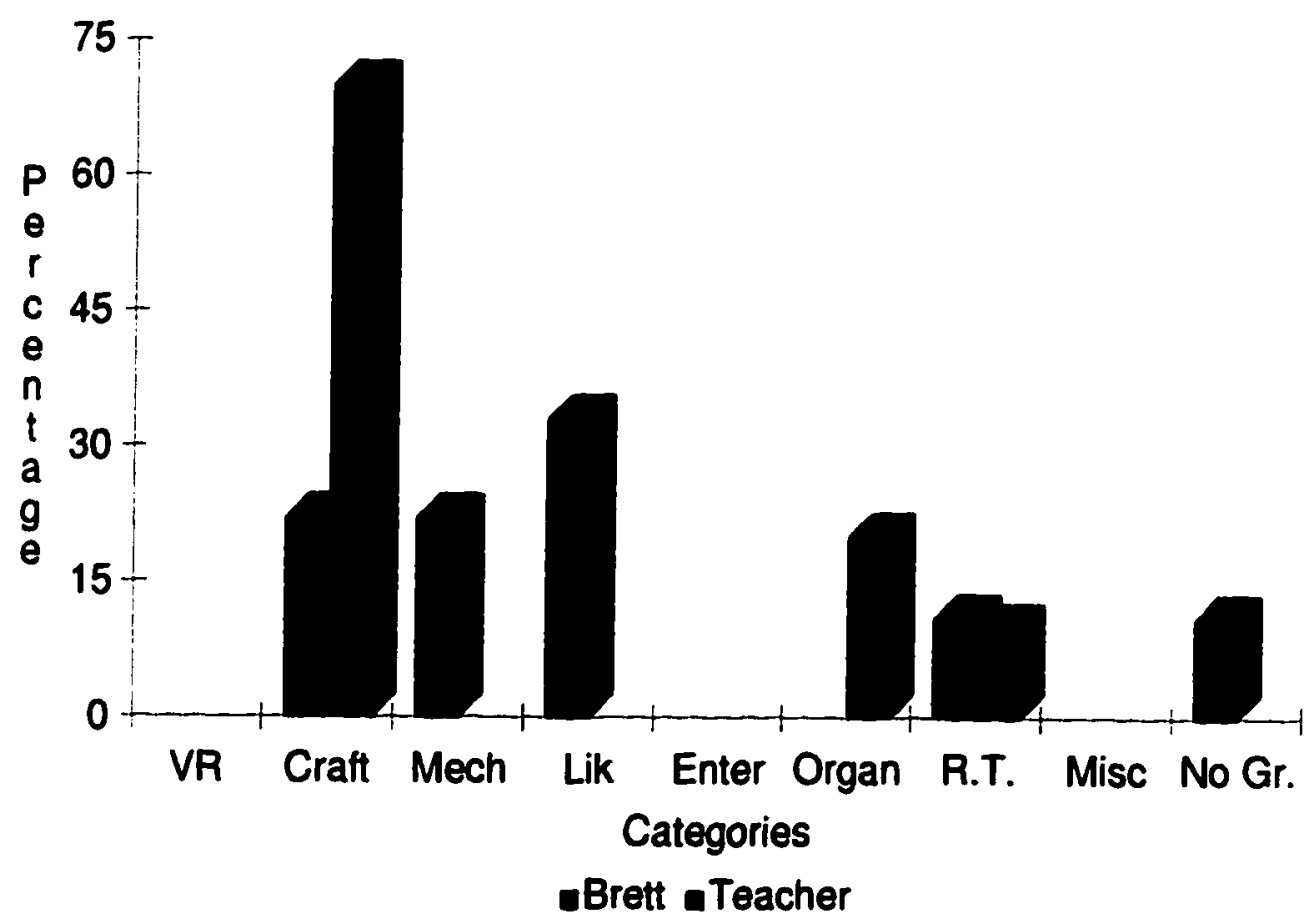

Key

\begin{tabular}{|l|l|}
\hline $\begin{array}{l}\text { Category } \\
\text { Abbreviation }\end{array}$ & Category \\
\hline VR & Value-Related \\
\hline Craft & Crafting \\
\hline Mech & Mechanics \\
\hline Lik & Liking \\
\hline Enter & Entertainment \\
\hline Organ & Organization \\
\hline R.T. & Risk-Taking \\
\hline Misc & Miscellaneous \\
\hline No Gr. & No Growth \\
\hline
\end{tabular}

